\title{
1. Innovation, IP and intellectual capitalism
}

Throughout man's past he has continually developed new techniques, but the pace has been slow and intermittent. The primary reason has been that the incentives for developing new techniques have occurred only sporadically. Typically, innovations could be copied at no cost by others and without any reward to the inventor or innovator. The failure to develop systematic property rights in innovation up until fairly modern times was a major source of the slow pace of technological change.

(North 1981, p. 164)

\subsection{AIMS AND OUTLINE}

This book aims at increasing our knowledge about how research and development (R\&D) of new technologies, patents and innovations through entrepreneurship can contribute to growth and ultimately to welfare in society and how growth and welfare in society in turn can contribute to more $\mathrm{R} \& \mathrm{D}$, patents and innovations for further growth and welfare, which in turn can contribute to more $R \& D$, patents and innovations for even more growth and welfare, which can contribute to even more . . ., etc. - in other words how to create and sustain a virtuous circle in an innovation system. The last $20+$ years have witnessed numerous attempts to achieve this through policies in one form or another in various innovation systems around the world. Innovation and entrepreneurship have become buzz words. At the same time a number of serious global challenges have emerged, challenges which in most cases have derived from use and overuse of old technologies, while at the same time calling for new technologies and innovations as necessary for dealing with them. New technologies and innovations called forth as remedies may in turn be used and overused and become sources of new challenges - in other words creating a vicious circle, shaping and being shaped by society.

The next $20+$ years will likely witness the emergence of new powerful innovation-based economies, notably in China and India, who both have declared their will to develop just that. ${ }^{1}$ Their economic systems are very different but subjected to common global driving forces that will reshape their economies and likely also their economic systems, although not necessarily force them to converge. Other nations with innovation-oriented aspirations are Indonesia, Singapore, Malaysia, Nigeria, S. Africa, Brazil, United Arab Emirates, Israel and Vietnam, to mention just a few. To highlight just a handful (that is to say five) of such common global driving forces and key trends one can point at:

1. The slow, gradual evolution of an ever more knowledge-based economy with a rising although fluctuating dominance of knowledge, including new technologies (i.e. new

\footnotetext{
1 The time window \pm 20 years from today is somewhat arbitrary but is useful for scenario-thinking, since it coincides with the maximal lifetime of individual patents, which normally is 20 years. This means that patents on inventions of today will normally last 20 years from now, and some patents on inventions 20 years ago have lasted until today.
} 
technical knowledge), and intellectual capital and assets in most industrialized and industrializing countries in conjunction with a continued deployment and strengthening of basic capitalist institutions, hence a continued evolvement of intellectual capitalism;

2. The continued development of the so-called pro-patent era within the framework of a new globalizing regime for governance of intellectual property (IP) resulting from fairly rapid policy developments in the 1980s and onwards;

3 . The continued internationalization and globalization with elements of market, economic, legal and technological convergence, setting the stage for the development of more aggressive innovation and IP policies, especially in key Asian countries (Japan, China, India, Japan, S. Korea ${ }^{2}$ and others);

4. The emergence of new generic and recombinant technologies (solar energy, biomaterials, robotics, machine intelligence, digitalization, etc.);

5. The emergence of more and larger global challenges (climate change, pandemics, poverty, overpopulation, wars and geopolitical instabilities, etc.).

A number of questions knock on our minds. How will and should innovation policies and innovation systems develop in the $20+$ years to come in this context with widely dissimilar nations with similar national innovation-oriented objectives, subject to common global forces? Will there be some form of convergence across nations as a result? What kind of innovation policies are helpful in improving innovation systems in general, including a global innovation system for meeting global challenges? What kind of R\&D and R\&D systems are needed? Does the patent system play any role in stimulating R\&D and innovations? What is the role of emerging new technologies of various kinds? And the even broader question: What kind of economic system, institutions and governance mechanisms are conducive for the provision of desirable new technologies and innovations of various kinds? Property rights have often been referred to as an institution that has played a major if not decisive role in the rise of Western economies but what about the role of IP rights in the continued emergence of more knowledge and innovation-based economies in the West and East? And the corollary question: How can we learn more about the linkages between R\&D, new technologies, innovations, growth and welfare to better answer these questions?

These are all grand questions and any attempt to provide some answers to them must be modest but at the same time not ignorant of the larger context. This book is hopefully such an attempt, in all modesty. The book builds on two investigations, one national and one international. The national investigation consists of a number of studies in connection with a Swedish government investigation of innovation and patent policies for growth and welfare, and the international investigation consists of a number of field studies in Asia, Europe and the US throughout a 10-year period as a follow-on investigation to the national one. A perspective on innovation policies from Sweden is a good reason for modesty at the outset, Sweden being a small country on the outskirts of Europe. On the other hand Sweden is highly ranked among countries in the world regarding indicators of innovativeness and welfare and thus provides if not a "best practice" case, at least a "good practice" case. Moreover, many policy lessons could be learned and taught across national borders, despite differences in scale, development stage, culture, economic

\footnotetext{
2 Throughout this book S. Korea stands for South Korea, i.e. the Republic of Korea.
} 
institutions and so on. That is in fact a common presumption in comparative studies of national innovation systems and policies. Europe and the EU have a special need for such studies and cross-country lessons about innovation policies, since their member states vary significantly in that regard, at the same time as synergistic integration is attempted as well as seriously challenged.

After having described the general aim and background of this book, as done so far, this introductory chapter will first elaborate on some key concepts in the book. The key trends mentioned above will then be elaborated followed by an analysis of cross-country statistics of R\&D, patents, innovations, growth and welfare to see how well different countries are doing and how these key variables correlate. Finally, an outline of the book is given together with reading guidelines.

\subsection{CONCEPTUAL FRAMEWORK}

The title of this book, Evolving Properties of Intellectual Capitalism: Patents and Innovations for Growth and Welfare, contains four of the key concepts in the book: patents, innovations, growth and welfare. Additional ones are research and development (R\&D), technology, intellectual property (IP) and intellectual capital (IC). They will be more precisely defined in subsequent chapters but for now shorthand descriptions will suffice (also see the Glossary). R\&D is searching and researching for new knowledge and ideas that can be useful in developing new things, soft or hard, typically new products and processes but also e.g. new services and business models. Some of this knowledge is privatized or propertized into IP. ${ }^{3}$ Technical knowledge, i.e. technology, can then under certain conditions be patented and registered as a patent right, being a special type of an IP right (IPR). A patent right to a specific technology can be used to exclude others from commercially using that technology without permission, normally for at most a period of 20 years. Innovations are things new to the world and proven to be useful to some extent. Innovations may through entrepreneurship lead to economic growth to some extent in terms of sales and value creations, and ultimately and hopefully to welfare in terms of quality of life, well-being and happiness. These key concepts denote processes and outcomes which are interrelated. For the sake of illustration, they could be ordered, at least roughly, in a causal but uncertain spiraling sequence with ideas and knowledge from R\&D tending to lead to IP and innovations, in turn tending to lead to growth and welfare, in turn tending to lead to investments in more R\&D, tending to lead to more innovations, etc., as shown in Figure 1.1.

Figure 1.1 thus gives a simple model of the innovation process, referred to in the following as the innovation spiral, in which the feedback from economic growth to R\&D is an essential feature. ${ }^{4}$ An important component of economic growth is growth of R\&D, new knowledge - including new technologies - and innovations, which in turn lead to growth of IC. Intellectual capital can be defined simply as non-physical, non-financial, or

\footnotetext{
3 Whether intangible knowledge could or should be seen as something that could in fact be propertized analogously to tangible things is a matter of controversy, see further Chapters 2, 3, 9 and 10 .

4 As will be described in Chapter 2, there are many models of innovation. Some of these models depict innovation processes as a linearly ordered set of activities and outcomes, a simplification that has been heavily criticized by innovation scholars. The model here is intentionally highly simplified, but not linear since it depicts a feedback mechanism.
} 


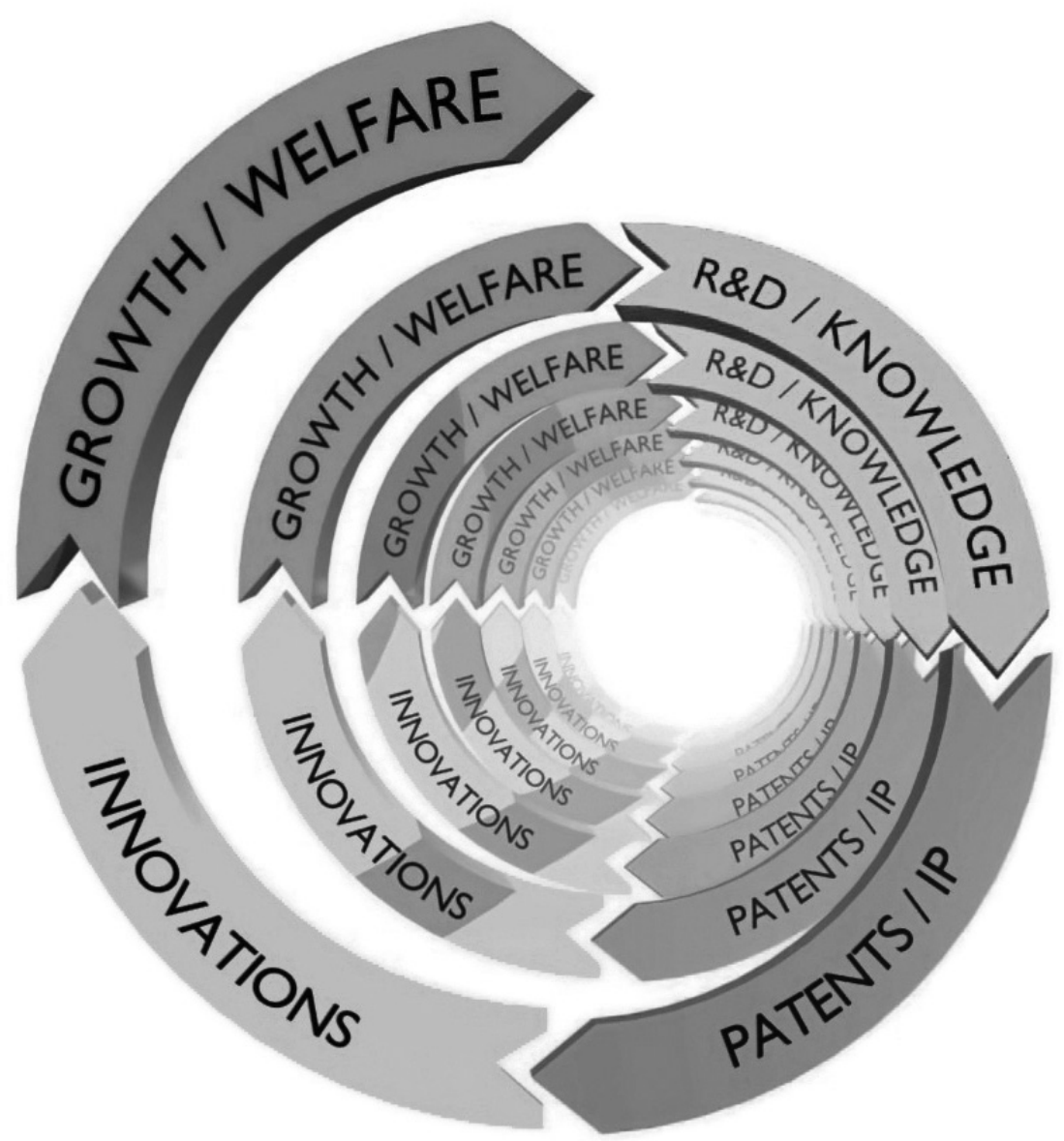

Figure 1.1 The innovation spiral

non-tangible (i.e. intangible) capital or capitalized intellectual resources or assets, while intellectual property can be defined as propertized intellectual resources or assets. ${ }^{5,6} \mathrm{An}$

\footnotetext{
5 Sometimes specific components of intellectual capital are referred to as R\&D capital, IP capital, knowledge capital, human capital, technology capital, innovation capital, organizational capital, relational capital, network capital, etc. OECD (2015a) for instance uses the term knowledge-based capital and regards this term as interchangeable with the term intangible assets.

6 Often patent rights are simply referred to in common language as "patents", trademark rights as "trademarks", etc. when there is no need to distinguish between the legally codified right to a creation and the creation itself. Similarly IPRs refer to legally codified rights while IP refers to the intellectual creations or resources (assets) themselves. See further Granstrand and Holgersson (2015).
} 
intellectual property right (IPR) is a legally recognized ownership right or usage right to some intellectual property. Common types of IPRs are patents for new, non-obvious and useful inventions; trademark rights for distinguishable identity marks; trade secret rights for secretly held valuable information; copyrights for artistic creations; and database rights for costly collections of data - all of them applying to intellectual creations of some kind. Ideas, knowledge, competence, network relations, IPRs and innovations are important intellectual resources and sources of IC, given that the benefits or returns from them can be captured or appropriated by companies and other actors, at least partly and temporarily.

The concept of an IP regime refers to a general mode or system for governing intellectual property oriented around various types of intellectual property rights and their associated legislation and means for enforcement. ${ }^{7}$ Such governance involves political leadership on national and international levels through laws and regulations, policies, interventions and institutions, such as markets and management in companies and other organizations, as well as technical and legal means of assistance. One can then distinguish between strong and weak IP regimes depending on the strength of legislation and enforcement. One could also talk about a patent or trade secret or copyright-oriented IP regime, in case there is a dominant IPR type for governance, say in a certain sector or industry.

These key concepts will be explicated more in Chapter 2 together with other concepts to be used in this book, such as innovation system and patent system.

\subsection{INTELLECTUAL CAPITAL AND ITS GROWING IMPORTANCE}

The emergence of a knowledge-based economy has taken place in some general sense gradually for centuries. If one has to point out a period of time when the economies in the major industrialized countries began to be dominated in some economic sense by knowledge and IC, it is the 1980s and 1990s. Looking at the causes behind this emergence, there are strong reasons to be techno-centric and emphasize the significance of the long accumulation of new technologies, i.e. new technical knowledge. ${ }^{8}$ In relation to resources and capital in general, knowledge has special properties which enable cumulation of value and long term wealth and welfare creation. For one thing, knowledge is not worn out or consumed but continues to grow, in an absolute sense, not the least through new combinations of existing knowledge elements, combinations which in turn constitute new recombinable knowledge elements etc. In relation to knowledge in general, technical knowledge in turn has further special properties which make it particularly cumulative, recombinant and value-creating in an economy. ${ }^{9}$ Most notably, new information and communication technologies have through digitalization enabled:

\footnotetext{
7 The concept of an IP regime is admittedly somewhat vague but commonly used (possibly due to its vagueness, since what is clearly vague is not clearly wrong).

8 See Granstrand (1998a, 1999, 2000a) for more detailed descriptions and analyses.

9 One can, of course, deepen the reasoning and take account of the risk that some knowledge will be destroyed through storage in physical or biological media (cf. "bit rot"), or that knowledge transfer across generations is impeded. A major slow-down of growth of collective knowledge due to such factors is not likely, however.
} 


\section{Evolving properties of intellectual capitalism}

1. Radically expanded and faster production, retrieval and global distribution and exchange of big sets of data, information and knowledge, resulting in various developments and applications becoming more sensor-, data- and computer-driven;

2. Reduction of search costs, interaction costs and transaction costs on markets in general, including markets for ideas, knowledge, technology markets and information markets, some of them with many small micro-transactions, whereby old markets become larger and more effective at the same time as completely new markets are created;

3. Increasing temporary privatization on the whole of data, information and other intellectual resources and their flows of returns through both legal and technical means (e.g. encryption, electronic codes, locks and firewalls, and streaming);

4. Creation of network-based scalable platforms for fast and large-scale communications and information exchange, social media and organized relation building and control (cf. e-commerce, e-government, e-research, etc.);

5. New technology combinations, e.g. in "intelligent" or "smart" products, processes and systems of widely varying types such as cars, houses, phones, weapons, materials, implants, etc., i.e. in various forms of machine intelligence, moreover to be connected by the "Internet of things" (IoT), and what could be called artificial intelligence (AI) and machine media, hybridizing with social media.

The collective stock of knowledge thus grows in an absolute sense (catastrophic destruction apart). This does not mean that neither economically useful knowledge, nor IC more generally will necessarily grow, since knowledge, and technologies not the least, may become obsolete and substituted for by new knowledge over time. Nor does it mean that IC will grow relative to other forms of capital, since scarcity of a vital primary physical resource (such as potable water) may conceivably arise to the point where its economic value growth contributes to a relative decline in IC's share of capital formation, and thereby possibly eliminates its dominance. Intellectual or intangible capital is moreover inherently difficult to measure. Nevertheless, many attempts have been made to do so and make comparisons with (more accurate) measures of tangibles. A number of indicators showed in the 1990s that IC had become ever more important, even dominant in the 1990s, such as investments in R\&D, and economic outcomes in terms of innovations and wealth growth. The question then is if any dominance of IC in an accounting sense is temporary or permanent. As it turns out the dominance of IC, expressed in stock market valuations around the world, was temporarily reduced but not permanently erased, neither by the bursting of the so-called information technology (IT) bubble and its affiliated "dotcom bubble" in the early 2000s, nor by the financial crisis in the late 2000s. However, fluctuations in company and asset valuations on financial markets appear to have become larger and more frequent and thereby leading to higher levels of more permanent volatility and risks in the economy which more easily could lead to reversals of any dominance of some capital component in the economy. ${ }^{10}$ Keeping all these cautious remarks in mind, Table 1.1 gives an overview of various indicators of the multi-faceted nature and importance of IC.

10 This is currently an open question. It is quite likely, however, that volatility in asset values will increase, and especially for intellectual assets. Some volatility of IP assets could also be created deliberately, e.g. by hedge funds thriving on volatility. (See further Chapter 10.) 


\section{Table 1.1 Indicators of the growing importance of intellectual capital}

\begin{tabular}{|c|c|c|}
\hline Indicator & Indication & References \\
\hline $\begin{array}{l}\text { 1. Ratio of intangible to } \\
\text { tangible investments }\end{array}$ & $\begin{array}{l}\text { Increase in both magnitude and } \\
\text { recognition of intangible assets } \\
\text { Ratio surpassed } 1.0 \text { for large Japanese } \\
\text { corporations in 1986, and for the US } \\
\text { around } 1995 \text {. China and most OECD } \\
\text { countries still below } 1.0 \text { but with an } \\
\text { increasing trend in the OECD }\end{array}$ & $\begin{array}{l}\text { Corrado et al. (2005, } \\
\text { 2006) } \\
\text { Uppenberg (2009) } \\
\text { TNO (1995) } \\
\text { Corrado et al. (2012) } \\
\text { Hulten and Hao (2012) } \\
\text { Kodama (1995) }\end{array}$ \\
\hline 2. Solow-type residual & $\begin{array}{l}\text { Aggregate growth is accounted for by } \\
\text { factors other than labor and physical } \\
\text { capital, primarily technology and } \\
\text { intangibles }\end{array}$ & $\begin{array}{l}\text { Corrado et al. (2012) } \\
\text { Uppenberg (2009) } \\
\text { Solow (1957) } \\
\text { Griliches (1996) }\end{array}$ \\
\hline 3. Tobin's $q$-value & $\begin{array}{l}\text { Emergence of IC-based companies (pure } \\
\text { as well as hybrid) }\end{array}$ & $\begin{array}{l}\text { Hall (1993) } \\
\text { Granstrand (1999) } \\
\text { Piketty (2014) }\end{array}$ \\
\hline $\begin{array}{l}\text { 4. IPR values (patents, } \\
\text { trademarks, trade secrets, } \\
\text { copyrights, designs, data } \\
\text { bases) }\end{array}$ & $\begin{array}{l}\text { Growing registration, value, litigation } \\
\text { and damage claims }\end{array}$ & WIPO (2014) ${ }^{b}$ \\
\hline $\begin{array}{l}\text { 5. IP-related crime and } \\
\text { misconduct }\end{array}$ & $\begin{array}{l}\text { Growth of intellectual theft, piracy, } \\
\text { counterfeiting and infringement, and } \\
\text { organizations dealing with these issues }\end{array}$ & PWC (2014) ${ }^{\mathrm{c}}$ \\
\hline $\begin{array}{l}\text { 6. Trade and transfer of } \\
\text { intellectual products }\end{array}$ & Emergence of technology markets & $\begin{array}{l}\text { Arora and Gambardella } \\
\text { (2010a) }\end{array}$ \\
\hline $\begin{array}{l}\text { 7. Wages related to human } \\
\text { capital (including personal } \\
\text { image value of 'stars') }\end{array}$ & $\begin{array}{l}\text { Growth of salary levels in intellectual } \\
\text { professions }\end{array}$ & $\begin{array}{l}\text { Strauss and de la } \\
\quad \text { Maisonneuve (2009) }\end{array}$ \\
\hline 8. Sources of personal wealth & Emergence of intellectual capitalists & Forbes $(2017)^{\mathrm{e}}$ \\
\hline 9. Sources of national wealth & $\begin{array}{l}\text { Intangible/intellectual capital } \\
\text { increasingly dominates the wealth } \\
\text { accounts of countries altogether }\end{array}$ & World Bank (2011) \\
\hline
\end{tabular}

Notes:

a A long series of papers on this and related issues can be found by Corrado, Hulten and others. Classifications, measurements and models are somewhat disputable and imprecise but improvements are made overtime. See also Chapter 3.

b Unambiguous trend seen in the world intellectual property organization (WIPO) statistics. Databases are not (yet) accounted for over time but likely emerge as an increasingly valuable resource (see e.g. The Economist, May 6, 2017).

c A study based on numbers from 'Performance \& Accountability Report' (USPTO) and 'Judicial Facts and Figures' (US Courts).

d A study of 21 OECD countries suggests that the wage premium on tertiary education has increased since the 1990 s.

e Forbes' 'The World's Billionaires' list contains a number of intellectual capitalists from the 1980s and 1990s such as Bill Gates (Microsoft) as well as today's latest intellectual capitalists such as Mark Zuckerberg (Facebook), Jeff Bezos (Amazon), Travis Kalanick (Uber), Jack Ma (Alibaba), Jan Koum (WhatsApp) and many more.

Source: Adopted and updated from Granstrand (1999). 


\section{Evolving properties of intellectual capitalism}

Accounting for IC and related concepts (intangibles, knowledge, human capital, etc.) involves many difficulties which have been described in the literature and will further be described in Chapters 2, 3 and 11. The difficulties derive from a variety of definitions, typologies and operationalizations of IC related to various accounting entities (firms, nations, etc.) with separation and aggregation problems, and from data unavailability and incompatible data sources and scales. ${ }^{11}$ Many of these accounting issues are well recognized, but new ones also appear as a result of new technologies. Just to mention a few new issues in IC accounting: Should the development of machine intelligence be accounted for as a type of physical capital or IC comparable to human capital and then what about humanoid capital? Should development of IoT communications be accounted for as relational (or network) capital comparable to relational capital among humans? Accounting difficulties apart, one could claim that developments like these will lead to increases in IC, as will big data analytics and developments in sensor technologies.

The accounting difficulties are compounded when any measure of IC is to be compared with measures of physical capital and its share of total capital, and further compounded if comparisons of absolute levels and relative shares over time are attempted. Just to mention one more issue: If a balance sheet is attempted at national or global level, and the inflow of solar energy or new space resources are accounted for, will that outweigh any increases in knowledge and IC?

Accounting difficulties notwithstanding, it is important to get some handle on the developments of IC for learning and policy decisions. To use a variety of indicators as illustrated in Table 1.1 is a first step, leaving refinements and aggregations to further research..$^{12}$ A question then is what indicates that the economy could be characterized as being or moving towards intellectual capitalism. Intellectual capitalism would be present (or approaching) in a strong sense if the share of IC as input and output in total capital formation is dominant (or increasing). That would be difficult to assess quantitatively in the present state of knowledge due to the accounting difficulties mentioned above. However, one can talk about intellectual capitalism in a weaker qualitative sense with references to various indicators showing IC to be of major importance, if not dominant, in different contexts. One can note here that the contemporary economy is frequently characterized as a knowledge-based economy, an innovation-based economy or an information-based economy, with little or no quantitative evidence. If that characterization is accepted then one question to be addressed is how the basic capitalist institutions - firms, markets, private profits and private property rights - are faring in the economy and how

11 See e.g. Howitt (1997), Granstrand (1999), Lev (2001), Corrado et al. (2005), Lin et al. (2014), Ståhle et al. (2015) and OECD (2015a). See also Lev and Gu (2016) for a more general critique of accounting and its functioning. Accounting for capital in general is similarly fraught with severe difficulties as illustrated by the most ambitious and impressive work of Piketty (2014) and the ensuing critique of its operationalizations and measures of capital, taken to exclude human capital but include intellectual (immaterial, intangible) capital besides physical and financial capital, all at market value totaled at national level and then equated with national wealth. (See further Chapter 3.)

12 An ambitious attempt to measure intellectual capital at national level and make cross-country comparisons is made in a series of studies reported in Lin et al. (2014). The studies use several categories of intellectual capital, with measures based on sets of indicators with different scales (ordinal, metric, etc.) allowing for scoring and ranking and some non-parametric tests. The methodology of the studies could be disputed as to the choice of intellectual capital categories and indicators, etc. as for any study of this kind. At the same time the studies illustrate the difficulties involved and after all represent a first large-scale attempt to construct measures of national intellectual capital (as distinct from the measures of total national capital in Piketty (2014)). 
they are affected by IC. ${ }^{13}$ This question will be briefly dealt with next and then returned to in Chapter 11.

As to firms, Table 1.1 and the references therein show that many, if not most, firms are IC based, consistent with previous research, although any trend in this respect is more of an open question after the financial crises in the early and late 2000s. IT firms like Amazon, Apple, Facebook, Google, Microsoft, etc. are certainly IC based and so are technology-based start-ups but so are also many firms based on natural resources. At the same time the large firms in the world economy account for most of the world's R\&D and patents.

As to markets, technology markets and data/information/knowledge markets more generally are growing nationally and internationally as also shown in Table 1.1. In periods and places international technology trade grows even faster than international trade in physical goods. ${ }^{14}$ The increasing use of various external technology acquisition and exploitation strategies, i.e. increasing use of open innovation, increases the demand for and supply of new technologies on technology markets (see further Chapter 2). The developments in "big data" and information gathering technologies and the rights in data (with the General Data Protection Regulation (GDPR) as just one example) can be expected to generate further importance and growth of data and information markets, and the increasing demand for intellectual talent and skills will further foster human capital markets.

Private profits and accumulation of private wealth many times derive from innovations and various types of intellectual assets, and several individuals could in fact be characterized as intellectual capitalists. Lists of wealthy individuals suggest that original (as opposed to inherited and the like) sources of personal wealth are increasingly intellectual in nature, although such lists must be interpreted with much caution.

Private property rights have gradually since the nineteenth century become extended with intellectual property rights, although there are inherent differences between physical and intellectual property and it is disputable to what extent IPRs should in fact be considered as "true" property rights. Nevertheless, IPRs are property-like in some important aspects and they are functional for trade in disembodied intellectual products. Some new types of sui generis IPRs, like database rights, have also been created. The surge in patenting, copyrights, trademarks, design rights and other IPRs indicate a rapidly growing role of them in the economy, as will be dealt with in the next section.

IPRs have also moreover affected other institutions in recent decades, notably universities. Universities are not a basic capitalist institution but have increasingly become an economic institution and as such indeed based on IC. As an economic institution universities have become an important component in national innovation systems. Universities have

13 There is a large literature on how to characterize capitalism in terms of evolving institutions and social relations and which institutions should be considered the basic ones, see Williamson (1985) and Hodgson (2015) for two thorough treatises with widely different perspectives on economic, legal and political institutions. Nevertheless there is a considerable consensus that firms, markets, profits and property rights are basic capitalist institutions, although there is a need to characterize them further, e.g. as entrepreneurial firms ("free enterprise"), competitive markets, private profits and private property rights, as well as a need to add other institutions like financial institutions and a special type of government in order to fully characterize capitalism.

14 Arora and Gambardella (2010b) estimate the average annual growth rate of technology trade in the G8 countries in the period 1980-2003 to be 10.7 percent while the worldwide "merchandise exports" grew annually with ca 7 percent in the same period according to World Bank statistics. 
also become more active in propertizing their IC with proactive patenting organized in technology transfer offices and the like, run by a new breed of university IP professionals.

Finally, most countries in the world have adopted capitalist economic institutions and most significant countries have some form of innovation policies and some of these, like China, India, Japan and S. Korea, are explicitly aiming at becoming innovation-based states, as will be described in the book. Although not phrased in terms of IC the close connection between innovation and intellectual capital justify talking of some countries as IC based, especially countries poor in indigenous natural resources like Japan and S. Korea. ${ }^{15}$

Thus, one is led to conclude that a new type of economy has by and large come to stay; an economy which is new in the sense that it has fairly recently begun to be dominated in some sense by knowledge and IC as pointed out by many scholars. The expression "the new economy" as used in the early years of the twenty-first century was rather misleading, though, being a suggestion that a wholly new economy had emerged and quickly replaced an old economy, while in fact all old, basic institutions in a capitalistic economic system private firms, markets, private profits, private property rights and a complementary government maintaining these institutions - were basically preserved. Rather, these institutions were reinforced and further internationalized during the 1990s after the fall of the Soviet empire and the changes in Asia, especially in the Chinese economic system. This new type of economy could consequently be called intellectual capitalism. ${ }^{16}$

\subsection{THE EVOLVING PRO-IP REGIME}

\subsubsection{Development of a New IP Rights System and a Pro-Patent Era}

In the beginning of the 1980s, but with roots further back in time, measures were initiated in the US, which led to a surprisingly fast and internationally broad transition to a new IP regime. The possibilities for acquiring and exploiting IPRs were strengthened in various ways, especially in the patent arena for exploiting new technologies. The US Supreme Court allowed patenting of living organisms in 1980 and patenting of software was allowed even earlier. A special Court of Appeals for the Federal Circuit (CAFC) was established in 1982 for patent cases. This court came to decide, far more often than previously, in favor of patent right holders and, at the same time, came to award much higher patent infringement damages, which US District Courts also started to do. This in total terms raised the value of a patent right generally, including the expected value of prospective patents, leading to a surge in patenting propensity and patenting frequency. ${ }^{17}$

15 As already mentioned, Lin et al. (2014) provides an attempt to measure national IC (NIC) for 48 countries and a ranking of them, albeit with no basis for judging them as IC-based or not.

16 There are several other labels as well for describing this type of capitalism, being based on knowledge, information or innovation. These labels are usually of the language form knowledge/information/innovation/ creative/intangible (based/intensive) capitalism/economy. In fact the flexible nature and variety of capitalist economies makes it hard to define and categorize them, something that is borne out by the abundance of qualifiers of capitalism in general in the literature, characterizing and labeling capitalism as x-capitalism with $\mathrm{x}$ being e.g. academic, alliance, American, Chinese, crony, global, Japanese, managerial, patrimonial, progressive, restless, state and so on.

17 See e.g. Granstrand (1999), Arora et al. (2003), Hall (2004), Jaffe and Lerner (2004), Bessen and Meurer 
A series of patent disputes then started, e.g. between the US and Japan, which developed into genuine "patent wars". 18

US authorities dealing with competition moreover changed their view of patents from seeing them as primarily encumbering static competition to seeing them primarily as promoting dynamic competition and innovations, albeit with static efficiency losses. The highest political and industrial management, including President Reagan and a number of congressmen and leaders of large companies (e.g. from Pfizer and IBM), actively pursued various issues and campaigns. New bills and regulations were introduced, although few essentially major changes in substantive law. Among other things, patenting by universities was facilitated through the Bayh-Dole Act 1980. International IP issues were brought over from GATT to WIPO and pursued actively by US negotiators as part of a so-called trade-related approach to IP issues, which resulted in the internationally important TRIPS agreement of $1994-95 .{ }^{19}$ (See further about TRIPS in Chapter 2.)

An important underlying cause behind these policy changes in the US was the threatening growth of the technology-based competitive power of especially Japanese industry, a threat that became obvious during the 1980s (although fading two decades later). Altogether these new policies implied the rise of the so-called "pro-patent era", first in the US and then spreading throughout much of the rest of the world, where it became dominant during the 1990s and 2000s, marking a clear and relatively fast transition from an old IP regime with generally weak IPRs in various countries to a new strong IP regime. The US strengthening of the IP system domestically and abroad also illustrates how IP policies can favor innovators against imitators and consequently be used for nationalistic purposes in an innovative nation for sustaining or exploiting its lead over countries trying to catch up.

The rapid emergence of a new pro-IP regime interacted with the much more gradual development of an increasingly knowledge-based economy. One might then ask which was the chicken and which the egg. Closer analysis indicates that the advent of a new pro-IP regime can be said to be more a consequence than a cause of the emergence of a knowledgebased economy in the form of intellectual capitalism. ${ }^{20}$ For example, it can be noted that the semiconductor, computer, software and telecom industries developed and produced the new information and communication technologies, which contributed significantly to the growth of IC formation, and these industries originally emerged before the pro-IP regime and the pro-patent era and then evolved without strong protection of IPRs. ${ }^{21}$ Figure 1.2 finally illustrates the growth of patenting in major economies in connection with the pro-patent era. ${ }^{22}$

(2008) and Burk and Lemley (2009). About the pros and cons of specialized courts for patents and the subsequent role of CAFC, see further Chapter 7.

18 See e.g. Warchofsky (1994), Granstrand (1999) and Chapter 10. It is interesting to note the possibility that this history repeats itself in the form of "IP wars", possibly embedded in "trade wars".

19 The TRIPS agreement was reached in 1994 and came into effect on January 1, 1995. See further e.g. Ryan (1998) and Scherer (2009).

20 See e.g. Coriat and Orsi (2002), Granstrand (2000, 2004), Hall (2004), Jaffe (2000) and Scherer (2009) for more detailed histories of the emergence of the pro-patent era. Based on these histories and counterfactual analysis of the likelihood of different sequences of major events, one could then argue that the emergence of the pro-patent era was more a consequence than a cause of the emergence of intellectual capitalism, although causality directions are blurred by numerous feedbacks.

21 See e.g. Mowery (1996), Samuelson (1993) and Granstrand (1999), as summarized in Fagerberg et al. (2005, p. 278).

22 These developments have been likened to a "patent explosion" (Hall, 2004) and a "patent surge" (Jaffe, 2000) and explained with several variants of the explanations offered here. 


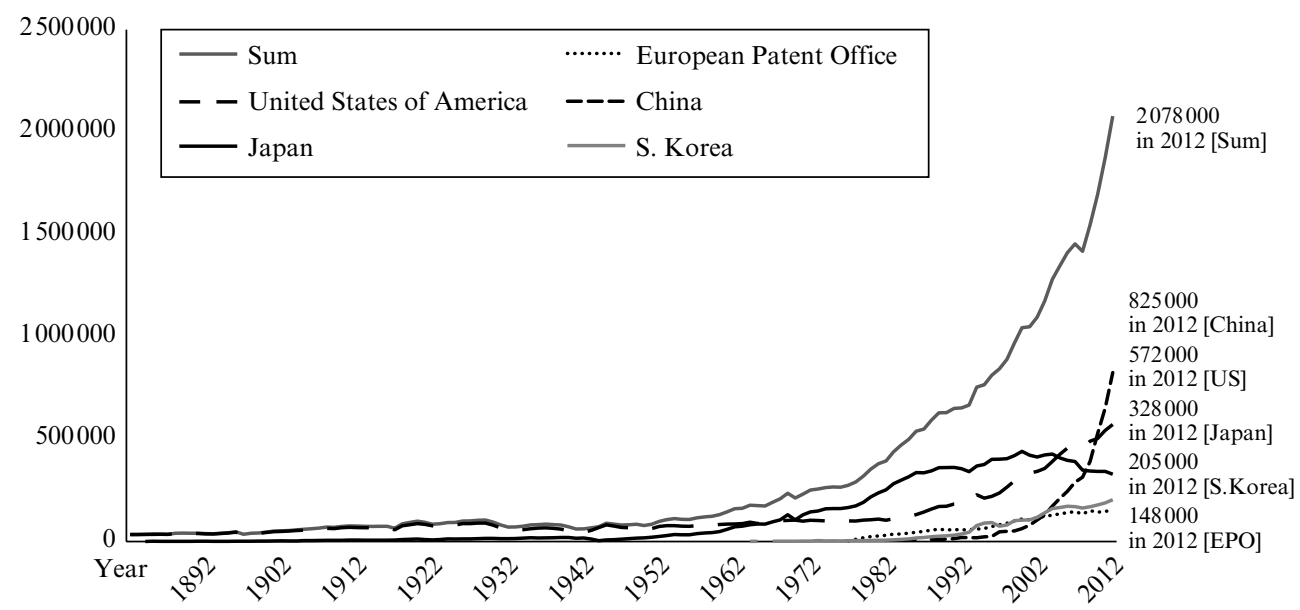

Source: WIPO statistics database. Collected from < https://www3.wipo.int/ipstats/index.htm $>$ (read April 1, 2018) in 2013 through 2018.

Figure 1.2 Number of annual patent applications in the top five filing patent offices

\subsubsection{Effects of the Pro-IP Regime}

Looking at the effects of intellectual capitalism and the pro-IP regime and its various interrelated managerial, economic, legal and technological trends, some effects are clearly visible whereas many can only be guessed. Still other effects are probably quite unimagined, and all we know about them is that we will be surprised. This is because it can be expected that fundamental differences between intellectual and physical capital will yield many deep-running and wide-ranging effects in the long term, e.g. in regard to economies of scale, synergies, communication economies, design and allocation of ownership rights, and transaction costs. A few visible effects are described below and some conceivable future ones are dealt with in Chapter 11.

\section{Strategy gaps and policy gaps}

At the micro-level of companies, one specific effect of the new pro-IP regime was a strategy gap that arose between company and business strategies on the one hand, and strategies for IC formation on the other - notably strategies for building up and exploiting IP assets, including new technologies and new technology combinations. With the rapidly growing importance of issues about IC and IP since the 1980s, these issues ceased to be mostly operative questions for experts and instead became strategic - even though at different rates in different industries. (Such issues had since long been strategic in the chemical and pharmaceutical industries, for example.) Accordingly, a need arose for formulating IP strategies, and integrating them with company and business strategies, and at the same time creating continuous involvement and commitment by company and business managers in IP issues. Often there was a lack of competence to satisfy this need, 
and sometimes even a lack of awareness of the need. Gradually this strategy gap has been narrowed by various means during the pro-IP era but still exists in many companies and industries. Similar situations of new needs in strategic management have arisen previously in industry, e.g., when issues of R\&D, technology and innovation emerged as strategic during the 1960s and 1970s, or when quality issues emerged as strategic in the 1980s.

At the macro-level of countries a similar gap arose at policy level. While many countries had R\&D policies, technology policies, industrial policies, economic policies and so forth, few had formulated innovation policies and even fewer patent and IP policies. Integration of patent and IP policies with other policies was by and large absent. This policy gap has been narrowed, especially by some key Asian countries as part of their catch-up policies, but still exists and one of the aims of this book is to narrow this policy gap through policy analysis and policy recommendations.

\section{Criticism}

In the aftermath of the advent of the pro-patent regime a strong critique of the IP system and the new IP regime emerged from diverse old and new directions, such as from developing countries (who always have criticized the IP system), from adherents of the so-called open-source movement in the software arena and from many economists. Criticism of the patent system has always existed, but now became reinforced, renewed and partly reoriented. The critics maintained that the new IP regime was designed far too much in the interests of large companies, especially the US ones, and that the new IP regime became counterproductive and rather hindered than promoted technical and economic progress. ${ }^{23}$ Critics further argued that, roughly speaking, patents were granted too frequently in many areas (e.g. for software and business methods) and too easily (e.g. with too low requirements on inventiveness), that patent disputes were too numerous and expensive, that small companies based on and dependent upon technology were disadvantaged - as were developing countries - and that the system simply had become too expensive when all costs, including transaction costs, were accounted for. ${ }^{24}$

A growing part of the criticism was (and is) informed and serious, at the same time the patent and IP area's increasing attention and popularity has attracted many new interest groups with highly variable insights and understandings - not least economists who, like many others, have largely neglected patent issues for a long period. The rapid pace of change from a weak to a strong IP regime gives, in itself, grounds for keeping watch on whether this trend has gone too far in certain respects as some fear. However, the state of knowledge about these questions has been and still (2018) is deficient for historical reasons, especially regarding empirical studies and experience, although the amount of studies is rapidly growing in the aftermath of the advent of a pro-IP regime. (See further Chapters 2, 3 and 9.)

23 Much patent reform efforts in the US have in fact been promoted by large US companies, thereby spurring critique and allegations of regulatory capture.

24 See especially Jaffe and Lerner (2004), National Research Council (2004), Bessen and Meurer (2008), Burk and Lemley (2009) and Boldrin and Levine (2008, 2013). See also Chapters 2, 9 and 10. 


\subsection{PATENT AND INNOVATION DEVELOPMENTS IN ASIA}

The development of an ever more IC-based and IP-oriented economy also interacts with strong historical tendencies towards greater internationalization and globalization. ${ }^{25}$ The strong economic long-run growth in Asia is well recognized in this regard. ${ }^{26}$ There are several reasons why many, if not most, countries in various stages of development will continue not only to pursue an energetic policy of innovation and growth, but also to integrate this policy with a proactive patent and IP policy at some stage. Moreover, a transition from a weak to a strong national IP regime can be made at a suitable stage of development with a change from a catch-up phase to a partial forge-ahead phase, although there may be large variations in development levels across industries and companies domestically. A strong IP regime then deters countries further down on the development ladder from freeriding in their acquisition of other nations' technologies. ${ }^{27}$ Such a transition took place in Asia, first in Japan and then in S. Korea and later in China, and is likely to take place in other countries as well at some point. The trend in India is still (2018) somewhat uncertain due to primarily domestic factors, but a number of economic and political aspects indicate that India will take the same development path. Table 1.2 gives a picture of how Asian countries have climbed the "patenting ladder" in the US during the pro-patent era. See also Table 6.19 in Chapter 6 for a more detailed picture. Table 1.3 further gives an opposite picture of how various countries have patented in China.

The consequences of these developments in Asia will be very important for European and US industry, not least for their small and medium-sized enterprises (SMEs). At present (2018) there is still a widespread and justified ambivalence in the industrial world in the West as to how China, and Asia in general, should be viewed from the standpoints of IP and technological protectionism. Anxiety over pirate copying, counterfeiting and "IP theft" is intense, not least among Western SMEs. However, from a Western standpoint the Western anxiety should be more concerned over what will happen - and what is already happening - when Chinese, Indian, S. Korean and other Asian companies patent on a large and strategically conceived scale, and when both small and large Western companies meet their patent fences, blankets or thickets and strategically built-up patent portfolios. ${ }^{28}$ Licensing deals, patent hold-ups and hold-outs (see further Chapters 2 and 3), patent extortionists, increased competition, reduced margins, "hire-overs" of key people, acquisitions and mergers and so on will probably multiply then, along with various patent and IP disputes, while much pirate copying and counterfeiting will survive at the same time. ${ }^{29}$

25 Several definitions of these concepts exist. Briefly, internationalization means an international expansion of an activity that preserves some degree of nationality and can occur from some form of center, while globalization means an international integration process in which national borders and nationalities play an ever more subordinate role, thus also involving a process of relative denationalization. See further Chapter 11 .

26 The historical as well as current and future importance of intra-Asian trade must at the same time be recognized.

27 See especially Abramovitz $(1986,1991)$ for the original notions of catch-up and forge-ahead and the rich literature on technological gaps and catch-up, e.g. Freeman et al. (1982), Fagerberg and Godinho (2005), Odagiri et al. (2010) and Lee (2013).

28 For an overview of different patent strategies and patent portfolio build-up configurations over time in the technology space, see Granstrand (1999) for an empirical study and Mihm et al. (2015) for a theoretical study.

29 From a Euro-centric standpoint one can develop scenarios by asking: What actually prevents some number of European firms, large as well as small, from becoming Chinese or Indian and even whole industrial 
Table 1.2 The top 20 patenting countries in the US from 1964 to $2014^{a}$

\begin{tabular}{rllllll}
\hline & 1964 & 1974 & 1984 & 1994 & 2004 & 2014 \\
\hline 1 & Germany & Germany & Japan & Japan & Japan & Japan \\
2 & UK & Japan & Germany & Germany & Germany & Germany \\
3 & France & UK & UK & France & Taiwan & S. Korea \\
4 & Switzerland & France & France & UK & S. Korea & Taiwan \\
5 & Canada & Switzerland & Canada & Canada & UK & China \\
6 & Japan & Canada & Switzerland & Taiwan & France & Canada \\
7 & Sweden & Sweden & Italy & Italy & Canada & France \\
8 & Netherlands & Italy & Netherlands & Switzerland & Italy & UK \\
9 & Italy & Netherlands & Sweden & S. Korea & Sweden & Israel \\
10 & Belgium & USSR & Australia & Netherlands & Switzerland & India \\
11 & Austria & Belgium & Austria & Sweden & Netherlands & Sweden \\
12 & Australia & Austria & Belgium & Australia & Israel & Italy \\
13 & Mexico & Australia & USSR & Belgium & Australia & Netherlands \\
14 & Denmark & Denmark & Finland & Israel & Finland & Switzerland \\
15 & Norway & Czechoslovakia & Israel & Finland & Belgium & Australia \\
16 & S. Africa & Finland & Denmark & Austria & Austria & Finland \\
17 & Czechoslovakia & Norway & Hungary & Denmark & Singapore & Belgium \\
18 & Argentina & Israel & Taiwan & Spain & Denmark & Austria \\
19 & Israel & Spain & Norway & Norway & China & Denmark \\
20 & Hungary & S. Africa & S. Africa & S. Africa & India & Singapore \\
\hline
\end{tabular}

Note: a The ranking is based upon the total number of patents granted to companies and other entities from each country listed. Origin of patent is based upon the residence of the first-named inventor. MNCs are also included. Bold marking marks the Asian countries and highlights their climbing on the list.

Source: US Patent and Trademark Office statistics collected from <https://www.uspto.gov/web/offices/ac/ ido/oeip/taf/reports.htm> (read April 1, 2018) in 2013 through 2018.

A notion that one can compete successfully with innovations alone is then precarious, partly because Japanese, Chinese, S. Korean, Indian and other companies in Asia and elsewhere will do so equally well or better and more cheaply - and partly since they also increasingly compete by using patents and other forms of IP protection. Japanese large companies have long shown proof of this. The old idea that Japanese industry - or Chinese industry for that matter - has only been clever at imitating, and finds it difficult to innovate, is on the whole obsolete. In addition to yielding results in Japan, Japan's national IP effort serves as a model for other Asian countries, even though the efforts there differ (see Chapter 9).

Thus one may fear from a Western standpoint that the US and the West has set a patent system and a pro-patent era in motion that will run counter to the original nationalist

sectors becoming Chinese or Asian controlled, with a significant part of European R\&D being effectively carried out, controlled by or transferred to India and China, within the course of a decade or two, or in other words within the span of a generation? As already mentioned, scenario-thinking could be developed by thinking 20 years - a standard patent's maximum lifespan - backward and forward in time. This means, e.g., comparing the trend during 1999-2019 with a possible trend during 2019-39. However, a warning is in order: To the extent that a phenomenon speeds up steadily, i.e. it accelerates, one can easily underestimate its future level. 
Table 1.3 The top 20 patenting countries in China from 1994 to $2014^{a}$

\begin{tabular}{llll}
\hline Rank & 1994 & 2004 & 2014 \\
\hline 1 & Japan & Japan & Japan \\
2 & US & US & US \\
3 & Germany & Taiwan & Germany \\
4 & France & S. Korea & S. Korea \\
5 & S. Korea & Germany & Taiwan \\
6 & UK & Netherlands & France \\
7 & Switzerland & France & Switzerland \\
8 & Taiwan & Switzerland & Netherlands \\
9 & Netherlands & UK & UK \\
10 & Sweden & Sweden & Cayman Islands \\
11 & Italy & Italy & Sweden \\
12 & Australia & Finland & Italy \\
13 & Finland & Canada & Austria \\
14 & Canada & Australia & Hong Kong \\
15 & Denmark & Hong Kong & Canada \\
16 & Austria & Denmark & Finland \\
17 & Belgium & Belgium & Denmark \\
18 & Hong Kong & Austria & Israel \\
19 & S. Africa & Israel & Belgium \\
20 & Israel & Singapore & Singapore \\
\hline
\end{tabular}

Notes:

a The narrow time span in the data is a result of limitations in the data provided by the Chinese patent office SIPO.

b The role and rank of different tax havens in patent statistics is conspicuous when looked at in more detail and does not correspond to any R\&D, in turn indicating a trade and transfer of "naked" patents, i.e. patents disintegrated from R\&D. See further Chapter 10.

Source: Data collected from SIPO by Y. Deyun at the University of Tokyo.

purposes behind it in the long run. However, such a Western standpoint might be unwarranted, not only because it is overly US-centric or Euro-centric but because it might be a false alarm from a growth and welfare point of view, not the least in light of the many serious global challenges, calling for more $\mathrm{R} \& \mathrm{D}$ and innovations around the globe. (See further Chapter 11.)

\subsection{DEVELOPMENT OF NEW PROTECTIVE TECHNOLOGIES}

Privatization of IC assets and capturing their flows of returns can occur not only by means of a strengthening of legal rights and policy changes, but also through diverse technological and managerial means. The balance between private and public IP may be upset by technological as well as by legal developments and thus may lead to excessively strong or weak opportunities for privatization and consequently to inadequately balanced incentives for investments in the provision of innovations. Balance in these respects is sought by limiting the duration, strength and scope of IPRs. Knowledge and intellectual 
creations thereby become public property after a certain time and thereby in that sense become "socialized". ${ }^{30}$ Technological developments in different areas can, from time to time, both increase and decrease the opportunities for private propertization respectively, as e.g. coding and decoding have. The extent of these effects from technological developments can and must naturally be discussed, e.g., regarding open-source movements, file sharing and lower imitation costs on the one hand and, on the other hand, regarding new protective technologies that are continually developed by private actors. These protective technologies are at the same time combined with legislation that, so far, has often been developed in the direction of facilitating privatization and then have become a basis for new business models. Examples of this exist in "copyright industries" such as those of music, film and databases, and in "research industries" such as biotechnology and information technology. For instance, databases are privatized through legal protection that is available e.g. in Europe, as well as through encryption and complex architecture which require specially made analytical tools in the form of software that (particularly in the US) in turn can be protected with patents, copyright and trade secrets. These databases and analytical tools (for "big data analytics") are upgraded more or less continuously, with compatibility backward and forward in time, whereby e.g. the tools can be protected or offered with high sales margins while the databases themselves may be almost given away for free. ${ }^{31}$ On the other hand, proprietary customer databases, e.g. derived from internet searches, computer gaming or e-commerce, may be a most valuable resource which constitutes the lion's share of a company's IC. ${ }^{32}$

\subsection{INNOVATION SPIRAL STATISTICS IN VARIOUS COUNTRIES}

Table 1.1 above showed various indicators of growth of intellectual capital such as $R \& D$ and intangible investments in order to highlight the question whether the global economy could be characterized as intellectual capitalism with a major if not dominant role of IC. In the movement towards such an economy new technologies and innovations of various types play a key role as mentioned. The question is now how the related variables in the innovation spiral have developed in various countries around the world. This question is difficult to answer beyond a mere description. Internationally standardized accounting measures and procedures exist for $\mathrm{R} \& \mathrm{D}$, patents and economic growth (typically

30 Note that in return for the option for someone to apply for and possibly obtain a patent right, the technical knowledge in the form of patent information in the patent application normally (usually after 18 months) becomes public regardless if a patent right is granted or not. The information thereby becomes freely available to everyone else, who in turn cannot freely use the information for commercial purposes without permission (license) from the patent right holder until any granted patent right expires. It must be noted that there is then a tension between the interests of society to have a sufficient disclosure of technical knowledge in return for the patent right and the interests of the patent applicant to reveal just as much as needed for the patent right and not "overpay" with valuable information. See further Chapter 2.

31 This low/high price structure for two complementary products is a long-standing, common business model for physical products, e.g. for razor/blades and camera/film. It will be interesting to watch the developments of such price structures for intellectual products and services, e.g. in areas like artificial intelligence and data analytics.

32 Cases in point are Facebook's acquisition of WhatsApp and Microsoft's acquisition of LinkedIn to get hold of their large customer or member databases. 
GDP-oriented) but not for innovations and welfare, although attempts to provide measures of these two latter variables exist and develop (typically index-oriented). The $\mathrm{R} \& \mathrm{D}$, patent and growth statistics nevertheless have limited reliability on an international scale with many measurement errors and missing data in various countries (e.g. regarding military R\&D). Finally, the limited availability of time series data precludes an analysis of statistical causality in the innovation spiral. Nevertheless the descriptive statistics with all their limitations provide a stimulus for thought, questioning and further research. The statistics below also provide a background for the reviews in Chapter 3 of the literature on the various components and relations in the innovation spiral, as well as a background for the review of selected countries in Chapter 9.

Tables 1.4-1.10 give some descriptive statistics about the different variables in the innovation spiral in various selected countries. The country selection in general includes OECD countries, major non-OECD countries and all the high ranking countries with respect to the variables in the innovation spiral, data availability permitting. Table 1.11 summarizes these types of statistics by means of the corresponding rankings for two periods of time. The available time series data is especially limited as to the indicators of innovativeness and of welfare (Global Innovation Index and Human Development Index). Some periodization is called for but available data (as of 2017) only allow for three 3-year periods and thus more refined time series analysis has to be left for future research.

Table 1.4 first shows the top $20 \mathrm{R} \& \mathrm{D}$ spenders among the selected countries in the year 2013. Skewness is apparent where the US, China and Japan altogether spends more on R\&D than the rest of the countries in the list, and more than the EU. For R\&D normalized as R\&D per capita (p.c.) and R\&D/GNI small countries appear at the top as do the US, Japan and S. Korea. The top ten R\&D spenders in absolute and relative terms are with some exception (Russia) not among the top ten countries in terms of their government $\mathrm{R} \& \mathrm{D}$ shares of their total R\&D. Thus, as seen in Table 1.4 , by far most R\&D is private among top R\&D spenders in the world.

Table 1.5 then gives the top 20 patentees among the patenting countries in the world. As will be dealt with in Chapters 6 and 8 , patent counting could be done in many ways and the patenting requirements differ across countries despite a fair amount of international harmonization. Here patent family (see the Glossary) counting is relied upon which could be taken as a measure of the amount of patented inventions. Number of patent families per R\&D dollar is then often interpreted as a measure of R\&D productivity, which easily is misleading since many factors influence the propensity to apply for and grant a patent for a given invention, as dealt with in Chapter 8 . Nevertheless the difference in this respect between China, Japan and S. Korea and other top patentees in absolute terms, such as US and Germany, is noteworthy although it may rather indicate a higher propensity to patent than a higher R\&D productivity. ${ }^{33}$

The patent system incentivizes $R \& D$, and counting patents is one way to assess $R \& D$ performance, albeit with limitations as mentioned. A system with prizes is another way with other limitations - to incentivize R\&D and assess its performance, as will be described

33 One could then ask whether these countries have more patents with lower technical quality or more narrow scope with fewer patent claims. This has not been the case regarding quality for Japan in the past as shown in Granstrand (1999) and is not a likely explanation for the large difference. Nevertheless, a more detailed further analysis, e.g. of number of claims and patent propensity, is justified. 


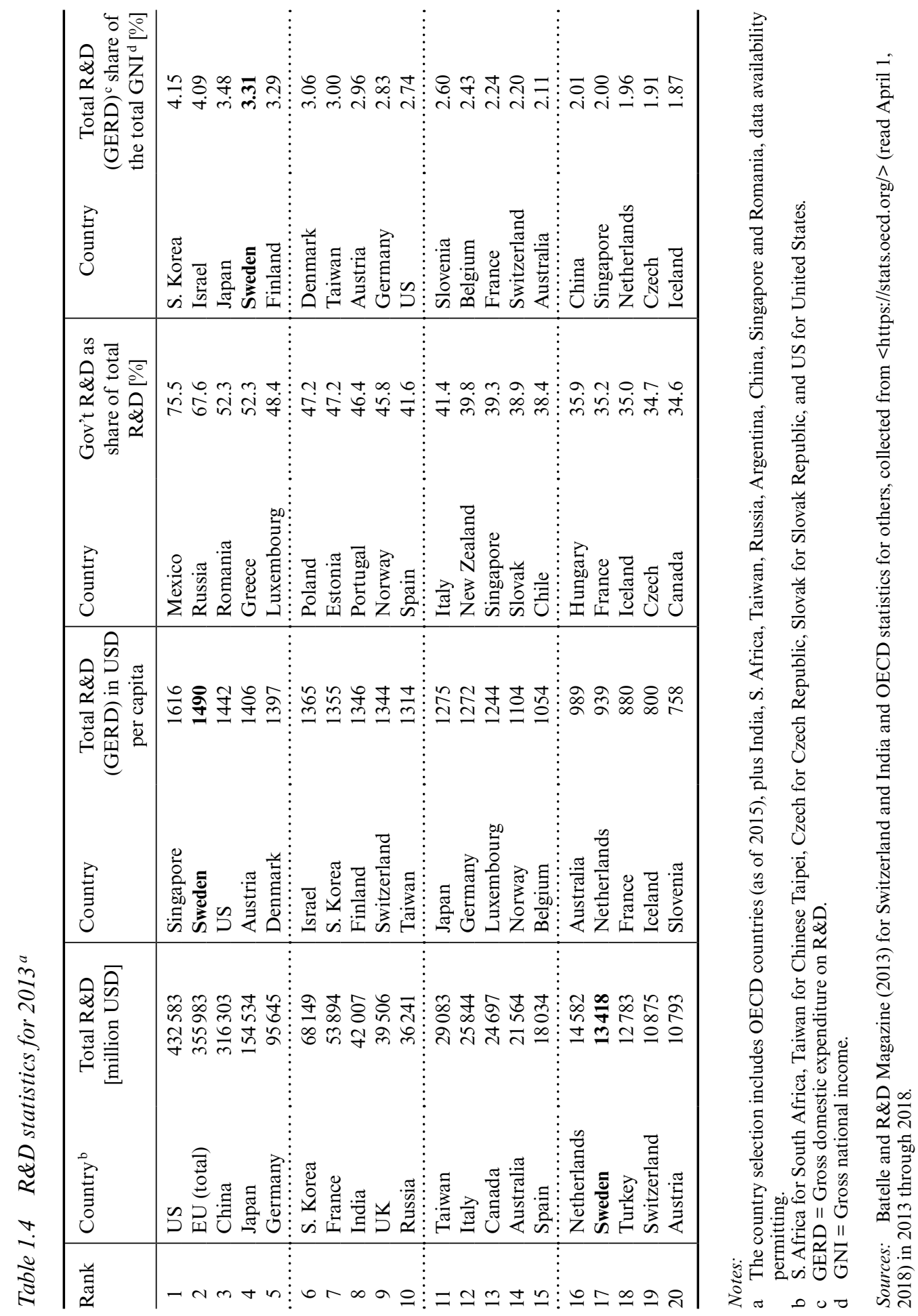


Table 1.5 Patent statistics for $2013^{a}$

\begin{tabular}{lcc|rc|rc}
\hline Country & Rank & $\begin{array}{c}\text { Total number of } \\
\text { patent families }\end{array}$ & Rank & $\begin{array}{c}\text { Patent families } \\
\text { per [100 000] } \\
\text { capita }\end{array}$ & Rank & $\begin{array}{c}\text { Patent families } \\
\text { per [\$ 10 million] } \\
\text { R\&D expenditure }\end{array}$ \\
\hline China & 1 & 593238 & 8 & 43.7 & 2 & 18.8 \\
Japan & 2 & 241783 & 2 & 189.9 & 3 & 15.6 \\
US & 3 & 159161 & 7 & 50.3 & 12 & 3.7 \\
S. Korea & 4 & 140768 & 1 & 280.3 & 1 & 20.7 \\
Germany & 5 & 50490 & 4 & 62.6 & 5 & 5.3 \\
Russia & 6 & 27077 & 14 & 18.9 & 4 & 7.5 \\
France & 7 & 17649 & 11 & 26.8 & 15 & 3.3 \\
UK & 8 & 15585 & 12 & 24.3 & 11 & 3.9 \\
Italy & 9 & 8992 & 15 & 14.9 & 13 & 3.5 \\
Canada & 10 & 8024 & 13 & 22.8 & 16 & 3.2 \\
Switzerland & 11 & 7013 & 3 & 86.7 & 6 & 5.1 b \\
Netherlands & 12 & 6977 & 9 & 41.5 & 8 & 4.8 \\
India & 13 & 6101 & 20 & 0.5 & N/A & N/A \\
Sweden & $\mathbf{1 4}$ & $\mathbf{5 7 7 6}$ & $\mathbf{6}$ & $\mathbf{6 0 . 2}$ & $\mathbf{1 0}$ & $\mathbf{4 . 3}$ \\
Poland & 15 & 4121 & 17 & 10.8 & 7 & 5.0 \\
Brazil & 16 & 3759 & 19 & 1.8 & N/A & N/A \\
Finland & 17 & 3371 & 5 & 62.0 & 9 & 4.6 \\
Spain & 18 & 3315 & 18 & 7.1 & 17 & 1.8 \\
Israel & 19 & 3301 & 10 & 41.0 & 14 & 3.3 \\
Australia & 20 & 3296 & 16 & 14.3 & 18 & 1.5 \\
\hline & & & & & & \\
\hline
\end{tabular}

Notes:

a A patent family is a family of patent rights in various jurisdictions for essentially the same underlying invention, and consists of a first filing for patent rights to the invention in one jurisdiction and subsequent filings in various countries.

b Based on R\&D expenditures 2012.

Sources: Number of patent families are collected from WIPO statistics database $(<\mathrm{https} / / / \mathrm{www} 3$.wipo. int/ipstats/index.htm >), R\&D expenditure from OECD statistics ( $<$ https://stats.oecd.org/>) and population numbers from World Bank statistics (<https://data.worldbank.org/>) in 2013 through 2018 (all read April 1, 2018).

in Chapter 2. A particularly prominent prize system in science and technology (S\&T) is the Nobel Prize system. Nobel Prizes and patents have in common that they are granted primarily on the grounds of quality of R\&D-based discoveries and inventions in S\&T terms rather than in economic terms (although their usefulness is taken into account as well).

Table 1.6 shows some Nobel Prize statistics. As can be seen these prize statistics give another picture of country rankings and in fact do not correlate at all with the patent statistics (the correlation coefficient is 0.01 and not significant). In fact, there are studies showing that the Nobel Prizes do not correlate well with economic growth either, which will be dealt with further in Chapter 3 .

Next, Table 1.7 shows the top 20 innovators plus some additional countries of interest among the countries in the world, based on two index-based measures. As seen the two measures are not highly correlated, which is a first call for caution in interpretation. 
Table 1.6 Nobel Prize statistics ${ }^{a, b}$

\begin{tabular}{lrc}
\hline Country & Total number of Nobel laureates & $\begin{array}{c}\text { Number of Nobel laureates per } \\
\text { [10 million capita }\end{array}$ \\
\hline Switzerland & 13 & 15.70 \\
Sweden & 7 & 7.14 \\
US & 209 & 6.50 \\
Norway & 3 & 5.78 \\
UK & 37 & 5.68 \\
Denmark & 3 & 5.28 \\
Israel & 4 & 4.77 \\
Belgium & 3 & 2.66 \\
France & 14 & 2.10 \\
Germany & 17 & 2.08 \\
Netherlands & 3 & 1.77 \\
Canada & 5 & 1.39 \\
Australia & 3 & 1.26 \\
Austria & 1 & 1.16 \\
Japan & 13 & 1.02 \\
Russia & 3 & 0.21 \\
Italy & 1 & 0.16 \\
China & 2 & 0.01 \\
\hline
\end{tabular}

Notes:

a Based on country of affiliation of all Nobel laureates with Nobel Prizes in physics, chemistry and medicine or physiology awarded in the period 1966-2016.

b The Pearson correlation coefficient of OECD countries between number of Nobel laureates per capita and $\mathrm{R} \& \mathrm{D} / \mathrm{GDP}$ is $0.45(\mathrm{p}<.01)$; between number of Nobel laureates per capita and patents per capita $0.01(\mathrm{p}<.98)$; between number of Nobel laureates per capita and GII $0.47(\mathrm{p}<.01)$; between number of Nobel laureates per capita and GDP growth $-0.12(\mathrm{p}<.5)$; between number of Nobel laureates per capita and HDI $0.41(\mathrm{p}<.01)$.

Sources: Nobelprize.org, <https://www.nobelprize.org/nobel_prizes/> (read July 5, 2017) and World Bank statistics collected from <https://data.worldbank.org/> (read April 1, 2018) in 2013 through 2018.

Moreover, as dealt with in Chapter 3, innovativeness measures like these are often a weighting of various factors, such as R\&D and patents which are limited, if not poor, indicators of innovativeness, which gives a second call for caution. (Most patents by far are never commercialized, for instance.) Innovation counting as an alternative, on the other hand, also presents a number of difficulties. Still another approach is to assess the share of sales (or GDP) that derives from new products and processes as used in the Community Innovation Survey (CIS) in the EU but again methodological problems arise (e.g. how to assess newness and identify impact on sales). Innovativeness or innovation performance is moreover a multi-dimensional concept that is difficult, if not impossible, to meaningfully reduce to a one-dimensional index-based measure. A key distinction that is often blurred but nevertheless needs to be upheld is between innovation effectiveness, referring to output of innovations, and innovation efficiency, referring to output of innovations in relation to resource inputs into innovation processes. Index-based measures of innovation inputs and outputs exist, although with caveats as mentioned, but acceptable measures 
Table 1.7 Innovation index rankings and scores 2014 and $2016^{a, b}$

\begin{tabular}{lll|llc}
\hline GII $^{\mathrm{c}}$ rank & Country & GII score & BII rank $^{\mathrm{d}}$ & Country & BII score \\
\hline $1(1)$ & Switzerland & $66.3(64.8)$ & $1(1)$ & S. Korea & $91.3(92.1)$ \\
$\mathbf{2 ( 3 )}$ & Sweden & $\mathbf{6 3 . 6}(\mathbf{6 2 . 3})$ & $2(5)$ & Germany & $85.5(88.2)$ \\
$3(2)$ & UK & $61.9(62.4)$ & $\mathbf{3}(\mathbf{2})$ & Sweden & $\mathbf{8 5 . 2}(\mathbf{9 0 . 8 )}$ \\
$4(6)$ & US & $61.4(60.1)$ & $4(4)$ & Japan & $85.1(90.4)$ \\
$5(4)$ & Finland & $59.9(60.7)$ & $5(8)$ & Switzerland & $85.0(86.0)$ \\
$6(7)$ & Singapore & $59.2(59.2)$ & $6(7)$ & Singapore & $84.5(86.1)$ \\
$7(11)$ & Ireland & $59.0(56.7)$ & $7(9)$ & Finland & $83.8(85.9)$ \\
$8(8)$ & Denmark & $58.5(57.5)$ & $8(3)$ & US & $82.8(90.7)$ \\
$9(5)$ & Netherlands & $58.3(60.6)$ & $9(6)$ & Denmark & $81.4(87.0)$ \\
$10(13)$ & Germany & $57.9(56.0)$ & $10(12)$ & France & $80.4(82.4)$ \\
$11(16)$ & S. Korea & $57.2(55.3)$ & $11(30)$ & Israel & $79.8(67.8)$ \\
$12(9)$ & Luxembourg & $57.1(56.9)$ & $12(18)$ & Russia & $78.9(77.5)$ \\
$13(19)$ & Iceland & $56.0(56.7)$ & 13 & Austria & 78.5 \\
$14(10)$ & Hong Kong & $55.7(56.8)$ & $14(14)$ & Norway & $77.1(80.8)$ \\
$15(12)$ & Canada & $54.7(56.1)$ & 15 & Ireland & 76.7 \\
$16(21)$ & Japan & $54.5(52.4)$ & 16 & Belgium & 76.2 \\
$17(18)$ & New Zealand & $54.2(54.5)$ & $17(16)$ & UK & $74.9(80.0)$ \\
$18(22)$ & France & $54.0(52.2)$ & $18(15)$ & Netherlands & $74.9(80.3)$ \\
$19(17)$ & Australia & $53.1(53.4)$ & $19(11)$ & Canada & $73.4(83.2)$ \\
$20(20)$ & Austria & $52.7(55.0)$ & $20(13)$ & Australia & $73.4(80.8)$ \\
$21(15)$ & Israel & $52.3(55.5)$ & $21(25)$ & China & $72.1(70.5)$ \\
$25(29)$ & China & $50.3(46.6)$ & 45 & India & 52.8 \\
$43(49)$ & Russia & $38.5(39.1)$ & $(45)$ & Brazil & $(54.4)$ \\
$54(53)$ & S. Africa & $35.9(38.2)$ & N/A & S. Africa & N/A \\
$66(76)$ & India & $33.6(33.7)$ & & & \\
$69(61)$ & Brazil & $33.2(36.3)$ & & & \\
\hline & & & & &
\end{tabular}

Notes:

a 2014 is shown in parentheses where data is available.

b The indexes of GII 2014 and GII 2016 have a rank correlation coefficient (Spearman's rho) of 0.93

$(\mathrm{p}<.001)$; GII 2014 and BII 2014 have a rank correlation coefficient of 0.47 ( $<<.05)$; GII 2016 and BII 2016 have a rank correlation coefficient of $0.50(\mathrm{p}<.05)$; BII 2014 and BII 2016 have a rank correlation coefficient of $0.81(\mathrm{p}<.001)$.

c GII is short for Global Innovation Index, based on 143 countries.

$\mathrm{d} \quad \mathrm{BII}$ is short for Bloomberg Innovation Index, based on 50 countries.

Sources: Cornell University, INSEAD, WIPO $(2014,2016)$ and Bloomberg $(2014,2016)$.

of innovation efficiency are still lacking. Such measures are much needed (just as any measure of productivity or rate of RoI is), e.g. for indicating innovation inefficiencies or the validity of any apparent $R \& D$ and productivity paradoxes described in Chapter 3 .

Thus, innovativeness at country level is simply difficult to measure in the current state of knowledge (as of 2018). Nevertheless, multiple measures and robustness tests can give some crude indications. For instance, there are no signs in Table 1.7 that the size of a country (in terms of population, GDP or R\&D) matters very much for its innovativeness. A statement that the most innovative countries are small thus has limited support (just as there is limited support for claiming that the most innovative firms are small). Incidentally, 
Table 1.8 National Intellectual Capital rankings

\begin{tabular}{lc}
\hline Country & Rank (2005-10) \\
\hline Sweden & $\mathbf{1}$ \\
Switzerland & 2 \\
Denmark & 3 \\
Finland & 4 \\
Singapore & 5 \\
Israel & 6 \\
US & 7 \\
Iceland & 8 \\
Norway & 9 \\
Netherlands & 10 \\
Austria & 11 \\
Canada & 12 \\
Australia & 13 \\
Hong Kong & 14 \\
Japan & 15 \\
Ireland & 16 \\
Germany & 17 \\
Taiwan & 18 \\
Belgium & 19 \\
UK & 20 \\
\hline
\end{tabular}

Source: Lin et al. (2014).

Sweden ranks highest in terms of the sum of the two ranks in the table, followed by US and Switzerland, and these three countries are also at the top of Table 1.6.

Table 1.8 then shows a ranking in terms of National Intellectual Capital (NIC), based on a fairly new index-based approach developed by L. Edvinsson, C. Lin, and others, as mentioned above. Small countries now dominate the top ranks. Caution in interpretation is called for again, however.

As to economic growth as a performance variable in the innovation spiral, Table 1.9 shows the average GDP growth rate for selected countries for three 3-year periods. As seen, China and India stand out. However, the financial crisis in 2008-10 led to a special shock-like downturn in growth in many countries, especially in Western countries. This notwithstanding, the variations in growth rates across countries and over time are considerable. Economic growth also has many determinants besides R\&D and innovations with varying strength across countries which will be dealt with in Chapter 3. A standard question in growth accounting and growth theory is then whether there is some type of convergence over time of economic growth across countries. Another question is whether there is any convergence of growth rates to a steady state of growth without business cycles for an economy. The data presented here are far too limited to shed light on such questions, but at least one could raise them by observing that the range of growth rate variation or growth fluctuations across countries do not decline over the three time periods (although the cross-country standard deviations do, but not significantly), nor do the growth fluctuations from period to period decline over time for the countries in general. 
Table 1.9 Growth statistics ${ }^{a, b, c}$

\begin{tabular}{|c|c|c|c|c|c|c|c|c|}
\hline Country & $\begin{array}{c}\text { Average } \\
\text { GDP } \\
\text { growth } \\
2006-8 \\
(\%)\end{array}$ & $\begin{array}{c}\text { Rank } \\
(2006-8)\end{array}$ & $\begin{array}{c}\text { Average } \\
\text { GDP } \\
\text { growth } \\
2010-12 \\
(\%)\end{array}$ & $\begin{array}{c}\text { Rank } \\
(2010-12)\end{array}$ & $\begin{array}{c}\text { Average } \\
\text { GDP } \\
\text { growth } \\
2013-15 \\
(\%)\end{array}$ & $\begin{array}{c}\text { Rank } \\
(2013-15)\end{array}$ & $\begin{array}{c}\text { GDP per } \\
\text { capita } \\
\text { in } 2016 \\
\text { USD } \\
(2016)\end{array}$ & $\begin{array}{l}\text { Rank } \\
\text { (2016) }\end{array}$ \\
\hline Ireland & 2.26 & 30 & 1.61 & 26 & 11.84 & 1 & 64175 & 3 \\
\hline Iceland & 5.29 & 11 & 0.04 & 37 & 3.61 & 6 & 60530 & 5 \\
\hline US & 1.38 & 40 & 2.12 & 21 & 2.37 & 22 & 57638 & 6 \\
\hline Singapore & 6.59 & 7 & 8.45 & 2 & 3.50 & 9 & 52962 & 8 \\
\hline Sweden & 2.51 & 29 & 2.79 & 15 & 2.79 & 14 & 51845 & 9 \\
\hline Australia & 3.48 & 20 & 2.67 & 17 & 2.53 & 18 & 49755 & 10 \\
\hline Germany & 2.68 & 28 & 2.74 & 16 & 1.39 & 28 & 42161 & 15 \\
\hline UK & 1.45 & 37 & 1.54 & 28 & 2.48 & 20 & 40412 & 17 \\
\hline New Zealand & 1.52 & 36 & 2.01 & 22 & 2.76 & 15 & 39412 & 18 \\
\hline Japan & 0.66 & 42 & 1.86 & 24 & 1.24 & 31 & 38972 & 19 \\
\hline Israel & 4.66 & 15 & 3.94 & 11 & 3.52 & 8 & 37181 & 20 \\
\hline France & 1.64 & 35 & 1.41 & 30 & 0.86 & 35 & 36857 & 21 \\
\hline S. Korea & 4.49 & 16 & 4.16 & 10 & 3.01 & 12 & 27539 & 23 \\
\hline Czech Republic & 5.05 & 12 & 1.08 & 33 & 2.51 & 19 & 18484 & 27 \\
\hline Slovak Republic & 8.29 & 2 & 3.17 & 14 & 2.70 & 17 & 16530 & 30 \\
\hline Latvia & 6.11 & 8 & 2.16 & 20 & 2.42 & 21 & 14071 & 32 \\
\hline Chile & 4.92 & 14 & 5.76 & 5 & 2.74 & 16 & 13793 & 33 \\
\hline Hungary & 1.71 & 34 & 0.23 & 36 & 3.23 & 10 & 12820 & 34 \\
\hline Poland & 5.82 & 9 & 3.41 & 13 & 2.84 & 13 & 12414 & 35 \\
\hline Turkey & 4.33 & 17 & 8.13 & 3 & 6.58 & 4 & 10863 & 36 \\
\hline Romania & 7.79 & 3 & 0.30 & 35 & 3.53 & 7 & 9523 & 37 \\
\hline Russia & 7.31 & 5 & 4.48 & 7 & -0.10 & 39 & 8748 & 38 \\
\hline Brazil & 5.04 & 13 & 4.47 & 8 & -0.09 & 38 & 8650 & 39 \\
\hline China & 12.20 & 1 & 9.34 & 1 & 7.32 & 2 & 8123 & 41 \\
\hline India & 7.65 & 4 & 7.45 & 4 & 7.30 & 3 & 1710 & 42 \\
\hline
\end{tabular}

Notes:

a The country selection includes OECD countries (as of 2018), plus India, Russia, China, Brazil, Singapore and Romania, data availability permitting.

b Average growth is here calculated as "Annual percentage growth rate of GDP at market prices based on constant local currency" whereas GDP is calculated as "the sum of gross value added by all resident producers in the economy plus any product taxes and minus any subsidies not included in the value of the products".

c The standard deviations across countries for the three consecutive time periods are 2.77, 2.62 and 2.57 respectively. The standard deviation of the range of variation across the three time periods is 2.01 . The range of variation across countries for each of the three time periods is $11.54,9.30$ and 11.94 respectively, and for the variations across them 12.30 .

Source: World Bank statistics collected from <https://data.worldbank.org/> (read April 1, 2018) in 2013 through 2018.

The ultimate objective variable(s) in the innovation spiral is welfare and its related concepts of wealth, well-being, happiness and quality of life. Again there are many measures and measurement problems just as for innovativeness, as further dealt with in Chapter 3. Table 1.10 shows three index-based measures for selected years and periods. The data availability over time is limited, however, which makes comparisons over time difficult. The three 
Table 1.10 Welfare indexes per country ${ }^{d}$

\begin{tabular}{|c|c|c|c|c|c|c|}
\hline Country & $\begin{array}{l}\text { Human } \\
\text { Development } \\
\text { Index }^{\mathrm{a}} \\
\text { Ranking } \\
\text { (2014) }\end{array}$ & $\begin{array}{c}\text { Human } \\
\text { Development } \\
\text { Index }^{\text {a }} \\
(2014)\end{array}$ & $\begin{array}{l}\text { World } \\
\text { Happiness } \\
\text { Report }^{\mathrm{b}} \\
\text { Ranking } \\
(2013-15)\end{array}$ & $\begin{array}{c}\text { World } \\
\text { Happiness } \\
\text { Report }^{\mathrm{b}} \\
\text { Index } \\
(2013-15)\end{array}$ & $\begin{array}{l}\text { SDG Index } \\
\text { ranking } \\
(1990-2015)\end{array}$ & $\begin{array}{c}\text { SDG } \\
\text { Index }^{\mathrm{c}} \\
(1990-2015)\end{array}$ \\
\hline Norway & 1 & 0.948 & 4 & 7.50 & 11 & 81 \\
\hline Switzerland & 2 & 0.938 & 2 & 7.51 & 19 & 78 \\
\hline Australia & 3 & 0.937 & 9 & 7.31 & 10 & 81 \\
\hline Germany & 4 & 0.924 & 16 & 6.99 & 15 & 80 \\
\hline Singapore & 4 & 0.924 & 22 & 6.74 & 2 & 85 \\
\hline Netherlands & 6 & 0.923 & 7 & 7.34 & 8 & 82 \\
\hline Denmark & 6 & 0.923 & 1 & 7.53 & 16 & 79 \\
\hline Ireland & 8 & 0.920 & 19 & 6.91 & 13 & 81 \\
\hline Canada & 9 & 0.919 & 6 & 7.40 & 9 & 81 \\
\hline Iceland & 9 & 0.919 & 3 & 7.50 & 1 & 85 \\
\hline US & 11 & 0.918 & 13 & 7.10 & 28 & 75 \\
\hline Hong Kong & 12 & 0.916 & 75 & 5.46 & N/A & N/A \\
\hline New Zealand & 13 & 0.913 & 8 & 7.33 & 30 & 74 \\
\hline Liechtenstein & 14 & 0.911 & N/A & N/A & N/A & N/A \\
\hline Sweden & 15 & 0.909 & 5 & 7.48 & 3 & 85 \\
\hline UK & 16 & 0.908 & 23 & 6.76 & 5 & 82 \\
\hline Japan & 17 & 0.902 & 53 & 5.92 & 27 & 76 \\
\hline S. Korea & 18 & 0.899 & 58 & 5.84 & 35 & 73 \\
\hline Israel & 19 & 0.898 & 11 & 7.27 & 23 & 77 \\
\hline France & 22 & 0.894 & 32 & 6.48 & 24 & 77 \\
\hline Finland & 23 & 0.893 & 5 & 7.41 & 6 & 82 \\
\hline Spain & 26 & 0.882 & 37 & 6.36 & 7 & 82 \\
\hline Andorra & 32 & 0.857 & N/A & N/A & 4 & 83 \\
\hline Russia & 48 & 0.805 & 56 & 5.86 & 119 & 54 \\
\hline Brazil & 79 & 0.754 & 17 & 6.95 & 90 & 60 \\
\hline China & 91 & 0.734 & 83 & 5.25 & 92 & 60 \\
\hline S. Africa & 119 & 0.665 & 116 & 4.46 & 134 & 46 \\
\hline India & 131 & 0.615 & 118 & 4.40 & 143 & 42 \\
\hline
\end{tabular}

Notes:

a The Human Development Index (HDI) is "a summary measure of average achievement in key dimensions of human development". These key dimensions are life expectancy at birth, years (or expected years) of schooling and GNI per capita.

b The World Happiness Report (WHR) is based on six variables: GDP per capita, social support, healthy life expectancy, freedom to make life choices, generosity and trust.

c The SDG Index is based on a number of the indicators on health related to the Sustainable Development Goals (SDGs) set up by the UN General Assembly in September 2015 (Lim et al., 2016). Note that this index is based on data from 1990 to 2015.

$\mathrm{d}$ The indexes of HDI and WHR have a rank correlation coefficient (Spearman's rho) of $0.66(\mathrm{p}<.001)$; HDI and SDG have a rank correlation coefficient of $0.49(\mathrm{p}<.05)$; WHR and SDG have a rank correlation coefficient of $0.56(\mathrm{p}<.005)$.

Sources: Helliwell et al. (2016), Lim et al. (2016) and United Nations Development Programme statistics collected from <http://hdr.undp.org/en/data> (read April 1, 2018) in 2013 through 2018. 
Table 1.11 Ranking of OECD countries regarding innovation spiral variables ${ }^{a, b}$

\begin{tabular}{|c|c|c|c|c|c|c|c|c|c|c|c|}
\hline \multirow[t]{2}{*}{ Country } & \multicolumn{2}{|c|}{ R\&D/GDP } & \multicolumn{2}{|c|}{$\begin{array}{l}\text { Patents per } \\
\text { capita }\end{array}$} & \multicolumn{2}{|c|}{ GII } & \multicolumn{2}{|c|}{ GDP growth } & \multicolumn{2}{|c|}{ HDI } & \multirow[t]{2}{*}{$\begin{array}{l}\text { Total } \\
\text { rank }^{\mathrm{c}}\end{array}$} \\
\hline & Early & Late & Early & Late & Early & Late & Early & Late & Early & Late & \\
\hline Australia & 13 & 14 & 15 & 18 & 15 & 18 & 16 & 15 & 2 & 3 & 9 \\
\hline Austria & 11 & 7 & 12 & 12 & 20 & 20 & 23 & 33 & 24 & 21 & 20 \\
\hline Belgium & 16 & 12 & 31 & 30 & 13 & 19 & 27 & 31 & 20 & 19 & 24 \\
\hline Canada & 15 & 21 & 25 & 27 & 8 & 11 & 29 & 20 & 10 & 9 & 19 \\
\hline Chile & 38 & 38 & 37 & 37 & 28 & 32 & 9 & 13 & 32 & 31 & 33 \\
\hline China & 22 & 16 & 21 & 6 & 25 & 29 & 1 & 2 & 37 & 37 & 21 \\
\hline Czech Republic & 24 & 18 & 26 & 25 & 27 & 24 & 8 & 16 & 25 & 26 & 25 \\
\hline Denmark & 9 & 6 & 9 & 11 & 10 & 8 & 34 & 26 & 5 & 4 & 7 \\
\hline Estonia & 28 & 20 & 33 & 33 & 26 & 21 & 14 & 19 & 28 & 28 & 26 \\
\hline Finland & 4 & 4 & 5 & 5 & 12 & 6 & 18 & 37 & 18 & 22 & 10 \\
\hline France & 14 & 13 & 8 & 9 & 5 & 22 & 31 & 32 & 17 & 20 & 18 \\
\hline Germany & 10 & 9 & 4 & 4 & 2 & 12 & 24 & 25 & 8 & 7 & 5 \\
\hline Greece & 34 & 35 & 29 & 31 & 36 & 36 & 22 & 38 & 25 & 27 & 35 \\
\hline Hungary & 31 & 25 & 24 & 28 & 30 & 27 & 30 & 8 & 30 & 33 & 31 \\
\hline Iceland & 7 & 19 & 22 & 24 & 18 & 15 & 7 & 5 & 13 & 13 & 13 \\
\hline Ireland & 23 & 24 & 23 & 29 & 19 & 9 & 26 & 1 & 4 & 12 & 16 \\
\hline Israel & 1 & 2 & 16 & 22 & 16 & 14 & 11 & 6 & 19 & 18 & 8 \\
\hline Italy & 29 & 27 & 13 & 17 & 21 & 28 & 37 & 36 & 23 & 24 & 27 \\
\hline Japan & 2 & 3 & 1 & 2 & 4 & 23 & 38 & 28 & 16 & 16 & 11 \\
\hline Luxembourg & 19 & 28 & 28 & 15 & 14 & 10 & 15 & 4 & 14 & 15 & 15 \\
\hline Mexico & 37 & 37 & 38 & 38 & 31 & 38 & 19 & 21 & 35 & 35 & 38 \\
\hline Netherlands & 17 & 17 & 19 & 21 & 9 & 4 & 21 & 29 & 7 & 5 & 14 \\
\hline New Zealand & 27 & 30 & 11 & 16 & 24 & 16 & 32 & 12 & 19 & 10 & 22 \\
\hline Norway & 21 & 23 & 17 & 20 & 22 & 13 & 28 & 24 & 1 & 1 & 16 \\
\hline Poland & 35 & 33 & 27 & 23 & 38 & 33 & 5 & 10 & 29 & 30 & 30 \\
\hline Portugal & 26 & 26 & 35 & 34 & 33 & 30 & 35 & 34 & 33 & 32 & 37 \\
\hline Russia & 30 & 31 & 10 & 10 & 37 & 34 & 3 & 35 & 34 & 34 & 28 \\
\hline S. Africa & 32 & 36 & 34 & 36 & 32 & 35 & 10 & 23 & 38 & 38 & 36 \\
\hline S. Korea & 5 & 1 & 2 & 1 & 17 & 17 & 12 & 9 & 21 & 17 & 4 \\
\hline Singapore & 12 & 15 & 20 & 19 & 7 & 5 & 4 & 7 & 15 & 6 & 6 \\
\hline Slovak Republic & 36 & 34 & 32 & 32 & 29 & 31 & 2 & 14 & 31 & 29 & 32 \\
\hline Slovenia & 20 & 11 & 18 & 14 & 34 & 26 & 6 & 27 & 22 & 23 & 23 \\
\hline Spain & 25 & 29 & 30 & 26 & 23 & 25 & 20 & 30 & 27 & 25 & 29 \\
\hline Sweden & 3 & 5 & 7 & 8 & 11 & 2 & 25 & 11 & 9 & 11 & 1 \\
\hline Switzerland & 6 & 8 & 14 & 13 & 6 & 1 & 17 & 22 & 3 & 2 & 1 \\
\hline Turkey & 33 & 32 & 36 & 35 & 35 & 37 & 13 & 3 & 36 & 36 & 34 \\
\hline $\mathrm{UK}$ & 18 & 22 & 6 & 7 & 3 & 3 & 33 & 17 & 12 & 14 & 12 \\
\hline US & 8 & 10 & 3 & 3 & 1 & 7 & 36 & 18 & 6 & 8 & 3 \\
\hline
\end{tabular}

Notes:

a The country selection includes OECD countries (as of 2015), plus Russia, China, Singapore and S. Africa, data availability permitting.

b Ranking in each variable for the average value of measurement, i.e. not rank, for the years 2006-8 (early), and 2010-12 (late) with GDP growth (late) as an exception in which case the period 2013-15 is used.

c Total rank is based on the sum of ranks. 
measures are moreover not highly correlated, which makes comparisons across countries difficult. Nevertheless, it is important to display the figures to underscore the difficulties as well as the need for better statistics. ${ }^{34} \mathrm{~A}$ few interesting observations could after all be made. There seems to be a size effect in the sense that "the happiest countries are small", while the fast growing large countries China and India rank low. Richer countries in terms of GDP p.c. also tend to rank higher. These observations bring in the question of the connections between growth, wealth and welfare, which will be dealt with in Chapter 3 . The questions about signs of any type of convergence could be raised but not answered here as well. As described in Chapter 3, other studies indicate that if anything there is rather a divergence of wealth levels in terms of gaps and divides across countries as well as within countries on average, and these levels have increased considerably over time in general.

Table 1.11 finally gives a summary of the rankings of OECD countries with regard to the different variables in the innovation spiral for the two 3-year periods just before and some years after the financial crisis and the ensuing great recession globally in 2008-10. ${ }^{35}$

As seen from Table 1.11 Sweden ranks overall fairly high among OECD countries on $\mathrm{R} \& \mathrm{D} / \mathrm{GDP}$, patents p.c., the Global Innovation Index (GII) index of innovativeness and the welfare indicator Human Development Index (HDI). These indicators naturally have many sources of errors as well as many determinants, many of which are country-specific and the need for caution in interpretation has repeatedly been pointed out above. Nevertheless there is room for cross-country learning. Just as Japan has provided many lessons for countries catching up, Sweden might provide many lessons for countries forging ahead, for instance.

A natural question then is what causality there is among the factors in the innovation spiral. Much can and has been said about this when it comes to R\&D, patents, and growth (see Chapter 3). However, not much could be inferred from the limited indicator data if innovativeness and welfare indicators are included and feedbacks are taken into account. A correlation matrix with correlations within and between three recent 3-year periods is shown in Table 1.12 as a simple illustration. As can be seen there are positive correlations between all factors except growth, which in turn was negatively correlated with all other factors in the innovation spiral. The negative (and insignificant) correlations probably have to do with the financial crisis at the time, while positive correlations are to be expected in general. As seen in the table cross-correlations across two consecutive 3-year periods are calculated but do not differ enough to indicate any causality in a time-lagged sense. This (lack of) result could be expected, given the naïve lag structure and the longer time lags and feedbacks between the factors. ${ }^{36}$

34 Better statistics also enable the use of multivariate statistical analysis. Available data and theoretical frameworks currently (as of 2018) do not allow for more refined multivariate regression analyses, let alone simultaneous equation modeling and structural equation modeling, in light of the many spiral variables with overlapping sets of variable indicators, inducing multicollinearities, and the many feedbacks. (For an interesting first attempt to use structural equation modeling for refining a national competitiveness index and country ranking, see Ju and Sohn (2014).)

35 These years are approximate as the timing and scale of the crisis and recessionary events varied across countries.

36 With a longer time series of the factors a test variable could be designed to test for time-lagged causality, based on the difference between forward and backward cross-correlations, a test variable that also could be used for non-parametric data. However, in the present lack of sufficient data this must be left for future research. In general Spearman's non-parametric rank correlations have been used here rather than Pearson's correlations since data are noisy and skewed, albeit at a probable loss of significance. Pearson's correlations have been calculated here as well as a robustness test of the qualitative findings in the text, which turn out to remain valid. 
Table 1.12 Spearman's rank correlations based on average values during the time periods 2006-8, 2009-11 and 2012-14 ${ }^{a, b}$

\begin{tabular}{|c|c|c|c|c|c|c|c|c|}
\hline & $\begin{array}{c}\text { R\&D/ } \\
\text { GDP 2006-8 }\end{array}$ & $\begin{array}{c}\text { R\&D/ } \\
\text { GDP } \\
2009-11\end{array}$ & $\begin{array}{c}\text { R\&D/ } \\
\text { GDP } \\
2012-14\end{array}$ & $\begin{array}{l}\text { Patents/ } \\
\text { capita }^{\mathrm{c}} \\
2006-8\end{array}$ & $\begin{array}{l}\text { Patents/ } \\
\text { capita } \\
2009-11\end{array}$ & $\begin{array}{l}\text { Patents/ } \\
\text { capita } \\
2012-14\end{array}$ & $\begin{array}{l}\text { GII }^{\mathrm{d}} \text { score } \\
2006-8\end{array}$ & $\begin{array}{l}\text { GII score } \\
2009-11\end{array}$ \\
\hline $\begin{array}{l}\text { R\&D/GDP } \\
2006-8\end{array}$ & 1.00 & $0.98^{* * *}$ & $0.94 * * *$ & $0.73^{* * *}$ & $0.70 * * *$ & $0.67 * * *$ & $0.84 * * *$ & $0.83^{* * *}$ \\
\hline $\begin{array}{c}\text { R\&D/GDP } \\
2009-11\end{array}$ & & 1.00 & $0.97 * * *$ & $0.73^{* * *}$ & $0.69 * * *$ & $0.65 * * *$ & $0.81^{* * *}$ & $0.79 * * *$ \\
\hline $\begin{array}{c}\text { R\&D/GDP } \\
2012-14\end{array}$ & & & 1.00 & $0.72^{* * *}$ & $0.70^{* * *}$ & $0.65 * * *$ & $0.75^{* * *}$ & $0.73^{* * *}$ \\
\hline $\begin{array}{l}\text { Patents/capita } \\
\text { 2006-8 }\end{array}$ & & & & 1.00 & $0.95^{* * *}$ & $0.89 * * *$ & $0.67 * * *$ & $0.64^{* * *}$ \\
\hline $\begin{array}{c}\text { Patents/capita } \\
2009-11\end{array}$ & & & & & 1.00 & $0.97 * * *$ & $0.64 * * *$ & $0.59 * * *$ \\
\hline $\begin{array}{c}\text { Patents/capita } \\
\text { 2012-14 }\end{array}$ & & & & & & 1.00 & $0.64^{* * *}$ & $0.55^{* * *}$ \\
\hline $\begin{array}{l}\text { GII score } \\
2006-8\end{array}$ & & & & & & & 1.00 & $0.86^{* * *}$ \\
\hline $\begin{array}{l}\text { GII score } \\
2009-11\end{array}$ & & & & & & & & 1.00 \\
\hline $\begin{array}{l}\text { GII score } \\
2012-14\end{array}$ & & & & & & & & \\
\hline $\begin{array}{l}\text { GDP growth } \\
2006-8\end{array}$ & & & & & & & & \\
\hline $\begin{array}{l}\text { GDP growth } \\
2009-11\end{array}$ & & & & & & & & \\
\hline $\begin{array}{l}\text { GDP growth } \\
2012-14\end{array}$ & & & & & & & & \\
\hline $\begin{array}{l}\text { HDI } \\
2006-8\end{array}$ & & & & & & & & \\
\hline $\begin{array}{l}\text { HDI } \\
\qquad 2009-11\end{array}$ & & & & & & & & \\
\hline $\begin{array}{l}\text { HDI } \\
\qquad 2012-14\end{array}$ & & & & & & & & \\
\hline $\begin{array}{l}\text { NIC } \\
2006-8\end{array}$ & & & & & & & & \\
\hline $\begin{array}{c}\text { GDP/capita } \\
2006-14\end{array}$ & & & & & & & & \\
\hline
\end{tabular}

Legend: Two tailed test. ${ }^{\dagger} \mathrm{p}<.10 ;{ }^{*} \mathrm{p}<.05 ;{ }^{* *} \mathrm{p}<.01 ;{ }^{* * *} \mathrm{p}<.001 . \mathrm{n}=34$ for NIC $2006-8 ; \mathrm{n}=40$ for others.

Notes:

a The country selection includes OECD countries (as of 2018), plus Russia, China, Singapore and S. Africa, data availability permitting.

b Squares include the bivariate correlations for the three time periods, triangles the univariate correlations between the three time periods.

c Patents/capita refers to patent families per capita.

d GII is missing from the compiled data for the years 2006 and 2008. Data normalized to the other years' indices.

e HDI was calculated with different measures for some of the included factors in the periods 2006-10 and 2011-16 respectively.

f NIC is limited to one time period due to data limitations.

Sources: INSEAD (2007, 2009, 2010); INSEAD and WIPO (2012); Cornell University, INSEAD, and WIPO (2013, 2014); Lin et al. (2014); OECD statistics (<https://stats.oecd.org/>), UNDP statistics (<http:// hdr.undp.org/en/data >), and World Bank statistics (<https://data.worldbank.org/>) collected in 2013 through 2018 (all read April 1, 2018). 


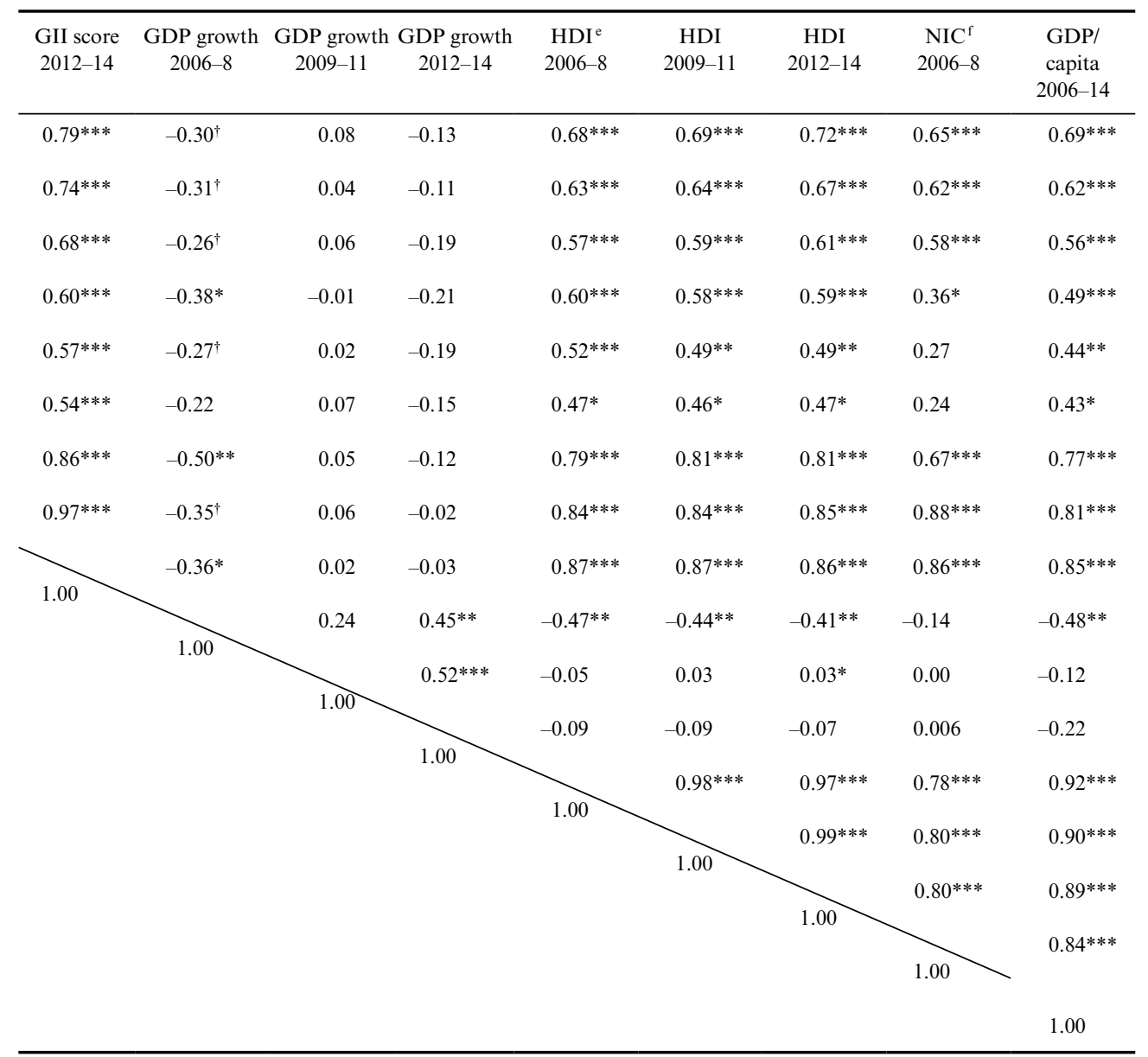

Referring the statistical causality in the innovation spiral to future research leaves us with the available rank correlations as rough indicators of the strength of the couplings in the innovation spiral across OECD countries. Table 1.12 then shows that R\&D is positively correlated with patents, innovation and welfare but not with growth, while patents are positively but weaker correlated with innovation and welfare but not with growth. Innovativeness is in turn stronger positively correlated with welfare. Again it must be kept in mind that the measures of the components in the innovation spiral are $R \& D /$ GDP, patent families p.c., Global Innovation Index, GDP growth and the HDI. Some of these measures are conceptually linked and the underlying variables are mutually causally linked with often long feedback cycles and the observation period here has been short and special, covering a severe financial crisis. Figure 1.3 summarizes the correlations found in the innovation spiral, averaged over the three time periods. 


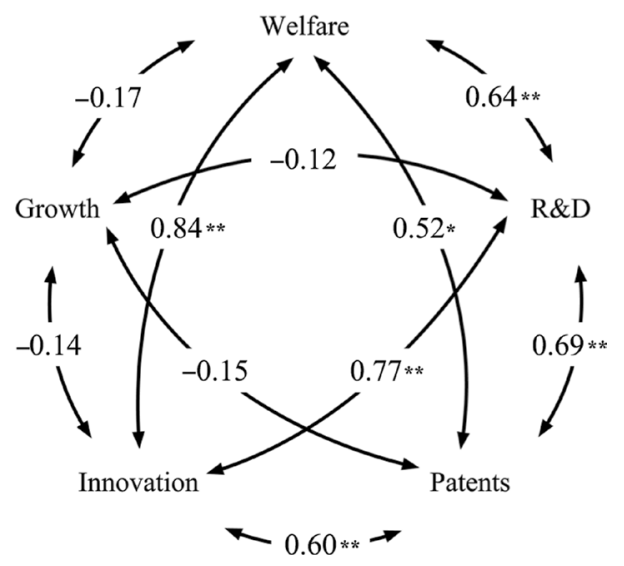

Notes:

a No causality is implied on statistical grounds.

$\mathrm{b}$ Two tailed test. ${ }^{*} \mathrm{p}<.01 ; * * \mathrm{p}<.001$. The number of observations is $\mathrm{n}=360$, where one data point per country and year corresponds to one observation. Values are calculated as averages of the Spearman's rho coefficients presented in Table 1.12 .

Figure 1.3 Average correlations found in the innovation spiral for OECD countries $(2006-14)^{a, b}$

\subsection{INSTITUTIONAL ENVIRONMENT}

Needless to say an innovation spiral at country level is embedded in an institutional environment. There are several measures and rankings that attempt to capture different qualities of this institutional environment. Of particular interest in innovation and IP policy analysis is the functioning of institutions related to government, firms, markets, property rights, universities and entrepreneurship. Table 1.13 gives measures and rankings for our country sample with regard to quality and quantity of government (proxied by government expenditure as a share of GDP), global competitiveness, entrepreneurship, rule of law and democracy. In addition to the general methodological reservations mentioned above one may add that the various indexes or indicators for the index-based variables are composed of slightly overlapping sets of variables, which induce a certain inbuilt correlation (i.e. multicollinearity). At closer scrutiny the compound indexes are nevertheless sufficiently independent for a first comparison of available data.

As seen in Table 1.13 small countries dominate the list of top 10 countries regarding each institutional variable, i.e. regarding entrepreneurship, quality of government, quantity of government, competitiveness, rule of law and democracy, and disproportionately so regarding quality of government, rule of law and democracy. ${ }^{37}$ The small countries on these six top-10 lists were moreover mostly Western European countries of old age.

37 The size of a country was classified as small (S), medium (M) or large (L) if its population size was less than 10 million, between 10 and 100 million or more than 100 million, respectively, in 2014 . Of the 38 countries in the sample 16 were small, 17 medium and 5 large. 
Table 1.13 Rankings over institutional qualities in selected countries in 2012-14 ${ }^{a, b}$

\begin{tabular}{|c|c|c|c|c|c|c|c|}
\hline Countries & $\begin{array}{l}\text { Entrepre- } \\
\text { neurship }^{c}\end{array}$ & $\begin{array}{l}\text { Quality of } \\
\text { government }^{\mathrm{d}}\end{array}$ & $\begin{array}{l}\text { Quantity of } \\
\text { government }^{\mathrm{e}}\end{array}$ & $\begin{array}{l}\text { Competi- } \\
\text { tiveness }^{f}\end{array}$ & $\begin{array}{c}\text { Rule of } \\
\text { Law }^{\mathrm{g}}\end{array}$ & Democracy $^{\mathrm{h}}$ & $\begin{array}{l}\text { Total } \\
\text { rank }^{\mathrm{i}}\end{array}$ \\
\hline US & 1 & 19 & 25 & 6 & 18 & 16 & 15 \\
\hline Canada & 2 & 9 & N/A & 11 & 12 & 8 & 5 \\
\hline Australia & 3 & 10 & 28 & 15 & 8 & 6 & 9 \\
\hline Sweden & 4 & 3 & 7 & 3 & 3 & 2 & 1 \\
\hline Denmark & 5 & 2 & 3 & 10 & 1 & 4 & 2 \\
\hline UK & 6 & 13 & 15 & 8 & 13 & 15 & 10 \\
\hline Switzerland & 7 & 6 & 29 & 1 & N/A & 7 & 8 \\
\hline Iceland & 8 & 16 & 14 & 23 & N/A & 3 & 13 \\
\hline Singapore & 9 & 11 & N/A & 2 & 9 & 35 & 14 \\
\hline Netherlands & 10 & 7 & 12 & 7 & 5 & 10 & 6 \\
\hline France & 11 & 21 & 2 & 16 & 15 & 22 & 17 \\
\hline Finland & 12 & 1 & 1 & 4 & 4 & 9 & 3 \\
\hline Germany & 13 & 12 & 16 & 5 & 10 & 14 & 11 \\
\hline Belgium & 14 & 17 & 5 & 13 & 16 & 21 & 16 \\
\hline Ireland & 15 & 15 & 24 & 21 & N/A & 12 & 19 \\
\hline Norway & 16 & 5 & 17 & 12 & 2 & 1 & 7 \\
\hline Austria & 17 & 14 & 8 & 14 & 7 & 13 & 12 \\
\hline Chile & 18 & 20 & N/A & 24 & 21 & 27 & 23 \\
\hline Israel & 19 & 23 & 22 & 20 & N/A & 30 & 25 \\
\hline Estonia & 20 & 22 & 26 & 25 & 14 & 28 & 24 \\
\hline Luxembourg & 21 & 8 & 19 & 17 & N/A & 11 & 18 \\
\hline Slovenia & 22 & 27 & 6 & 34 & 24 & 26 & 27 \\
\hline S. Korea & 23 & 26 & 30 & 18 & 17 & 17 & 22 \\
\hline Turkey & 24 & 35 & N/A & 31 & 29 & 36 & 35 \\
\hline Portugal & 25 & 25 & 10 & 30 & 23 & 25 & 26 \\
\hline Spain & 26 & 24 & 13 & 26 & 19 & 20 & 21 \\
\hline Japan & 27 & 18 & 23 & 9 & 11 & 18 & 20 \\
\hline Poland & 28 & 29 & 20 & 28 & 20 & 32 & 30 \\
\hline Slovakia & 29 & 30 & 21 & 37 & N/A & 31 & 33 \\
\hline Czech Republic & 30 & 28 & 18 & 27 & 22 & 19 & 28 \\
\hline Hungary & 31 & 31 & 11 & 35 & 26 & 33 & 32 \\
\hline Italy & 32 & 32 & 9 & 29 & 25 & 24 & 29 \\
\hline Greece & 33 & 33 & 4 & 38 & 27 & 29 & 31 \\
\hline S. Africa & 34 & 34 & N/A & 32 & 28 & 23 & 34 \\
\hline China & 35 & 37 & N/A & 22 & 30 & 38 & 36 \\
\hline Russia & 36 & 38 & 27 & 36 & 32 & 37 & 38 \\
\hline Mexico & 37 & 36 & N/A & 33 & 31 & 34 & 37 \\
\hline New Zealand & N/A & 4 & N/A & 19 & 6 & 5 & 4 \\
\hline
\end{tabular}

Notes:

a The country selection includes OECD countries (as of 2015), plus Russia, China, Singapore and S. Africa, data availability permitting.

b See rank correlations between indices in Table 1.14.

c Global Entrepreneurship Index average over 2012-14. The index is based on 14 multivariate factors: opportunity perception, start-up skills, risk acceptance, networking, cultural support, opportunity start-up, technology absorption, human capital, competition, product innovation, process innovation, high growth, internationalization, and risk capital. Data collected from Ács et al. (2014, 2015, 2016).

d Measured as the average over 2012-14 of the six multivariate factors in the Worldwide Governance. 


\section{Table 1.13 (continued)}

Indicators dataset: voice and accountability, political stability and absence of violence, government effectiveness, regulatory quality, rule of law, and control of corruption.

e Average government expenditure as share of GDP over 2012-14.

f Global Competitiveness Index average over 2012-14. The index is based on 12 multivariate factors: institutions, appropriate infrastructure, macroeconomic environment, health and primary education, higher education and training, goods market efficiency, labor market efficiency, financial market development, technological readiness, market size, business sophistication, and innovation. Data collected from World Economic Forum (2011, 2012, 2014).

g Rule of Law Index average over 2012-14. The index is based on eight multivariate factors: constraints on government powers, absence of corruption, open government, fundamental rights, order and security, regulatory enforcement, and criminal justice. Data collected from The World Justice Project $(2013,2014)$.

$\mathrm{h}$ Democracy Index average over 2012-14. The index is based on five multivariate factors: electoral process and pluralism, civil liberties, the functioning of government, political participation, and political culture. Data collected from Economist Intelligence Unit (2012, 2013, 2014).

i Ranking based on the sum of all other rankings in table. Where no rank is available ("N/A"), the average of available ranks has been added for the particular country.

Sources: Ács et al. (2014, 2015, 2016); Economist Intelligence Unit (2012, 2013, 2014); OECD statistics (<https://stats.oecd.org/>) and World Bank statistics (<https://data.worldbank.org/>) collected in 2013 through 2018 (both read April 1, 2018); World Economic Forum (2011, 2012, 2013); World Justice Project $(2013,2014)$.

EU countries moreover dominated the top-10 list regarding quantity of government. (This variable had several missing and questionable data, however.) Large countries on the other hand were absent from these lists with the occasional exceptions of the US and Japan, and thus disproportionately so. The Pearson correlations between country size and the quality of government, rule of law and democracy indexes were also significantly negative (around -0.5 ) while country size did not matter for competitiveness and entrepreneurship.

Table 1.14 moreover shows that the selected institutional variables are all strongly positively correlated except for quantity of government, which is most weakly connected to all the other variables. The weak connect between quality and quantity of government is noteworthy, and in need of further exploration, which falls outside the scope here, however. The strong connect between quality of government and rule of law is also noteworthy, but partly derives from the construction of the indices, something that applies to the other strong correlations as well.

Finally, as seen from Table 1.15 all the indices for institutional qualities except quantity of government strongly correlate positively with all innovation spiral variables except patents and growth, although with less significance between democracy and R\&D. The negative correlations between democracy and growth and between quantity of government and growth are noteworthy as are the negative significant correlations between growth and the other indices. The growth variable was however distorted by the financial crisis and not much can be deduced from it in this context, unfortunately. Quantity of government was somewhat disconnected from the innovation spiral, except for growth in some years, which again is noteworthy, especially in light of the many strong connections between quality of government and other variables. Another somewhat disconnected variable, but perhaps less surprising, is the patent variable. Thus, on the basis of this limited analysis, one may hypothesize, if not claim, that large low quality governments 
Table 1.14 Rank correlation between institutional indexes ${ }^{a}$

\begin{tabular}{|c|c|c|c|c|c|c|}
\hline & $\begin{array}{l}\text { Entrepre- } \\
\text { neurship }\end{array}$ & $\begin{array}{l}\text { Quality of } \\
\text { government }\end{array}$ & $\begin{array}{l}\text { Quantity of } \\
\text { government }\end{array}$ & $\begin{array}{l}\text { Competi- } \\
\text { tiveness }\end{array}$ & $\begin{array}{l}\text { Rule of } \\
\text { Law }\end{array}$ & Democracy \\
\hline Entrepreneurship & 1.00 & $0.84 * * *$ & 0.25 & $0.79 * * *$ & $0.82 * * *$ & $0.71 * * *$ \\
\hline $\begin{array}{l}\text { Quality of } \\
\text { government }\end{array}$ & & 1.00 & $0.35^{*}$ & $0.84 * * *$ & $0.99 * * *$ & $0.84 * * *$ \\
\hline $\begin{array}{l}\text { Quantity of } \\
\text { government }\end{array}$ & & & 1.00 & 0.17 & $0.36^{*}$ & $0.42 * *$ \\
\hline Competitiveness & & & & 1.00 & $0.82 * * *$ & $0.64 * * *$ \\
\hline Rule of Law & & & & & 1.00 & $0.85 * * *$ \\
\hline Democracy & & & & & & 1.00 \\
\hline
\end{tabular}

Legend: Two tailed test. ${ }^{*} \mathrm{p}<.05 ; * * \mathrm{p}<.01 ;{ }^{* * *} \mathrm{p}<.001$.

Notes: a Correlation coefficient calculated as Spearman's rho.

Sources: Ács et al. (2014, 2015, 2016); Economist Intelligence Unit (2012, 2013, 2014); OECD statistics (<https://stats.oecd.org/>) and World Bank statistics (<https://data.worldbank.org/>) collected in 2013 through 2018 (both read April 1, 2018); World Economic Forum (2012, 2013, 2014); World Justice Project (2013, 2014).

on average are connected with weak innovation spirals, while strong innovation spirals on average are connected with small countries with high quality democratic governments and strong rule of law, with caveats about the growth factor.

\subsection{BOOK AIMS, OUTLINE AND READING GUIDELINES}

\subsubsection{Book Aims and Limits}

The general aim of this book is to offer a research-based analysis of the linkages between R\&D, patents, innovations, growth and welfare as mentioned above. More specifically the aim is to present a policy study which is evidence-based and formulate policy recommendations in a national policy perspective as well as in an international perspective. A subsidiary aim of the book is to clarify a number of key concepts and distinctions in an attempt to contribute to a professional language in the innovation policy area, an area which is filled with rhetoric fashions and fads for various reasons, not the least due to its rapidly growing popularity among policy-makers and the public at large. The book also aims to contribute to research in the innovation and IP area by offering research questions and methods. Study design and questionnaires have for that aim been aligned with research questions in previous studies and presented in some detail, together with a number of recommendations for further IP policy research.

\subsubsection{Research Basis}

The empirical base consists of two main investigations. First a large package of substudies performed in connection with a national Swedish government investigation 
Table 1.15 Spearman's rank correlations between institutional variables and innovation spiral variables

\begin{tabular}{|c|c|c|c|c|c|c|}
\hline & $\begin{array}{l}\text { Global } \\
\text { Entrepren- } \\
\text { eurship } \\
\text { Index }^{\mathrm{a}} \\
2014-16\end{array}$ & $\begin{array}{l}\text { Quality of } \\
\text { government }^{\text {b }} \\
\text { 2012-14 }\end{array}$ & $\begin{array}{l}\text { Quantity of } \\
\text { government }^{\mathrm{c}} \\
\text { 2012-14 }\end{array}$ & $\begin{array}{l}\text { Global } \\
\text { Competi- } \\
\text { tiveness } \\
\text { Index d }^{\mathrm{d}} \\
2012-14\end{array}$ & $\begin{array}{l}\text { Rule of } \\
\text { Law }^{\mathrm{e}} \\
2012-14\end{array}$ & $\begin{array}{c}\text { Democracy } \\
\text { Index f }^{\text {f }} \\
2012-14\end{array}$ \\
\hline R\&D exp. 2006-8 & $0.67 * * *$ & $0.66^{* * *}$ & 0.37 & $0.77 * * *$ & $0.64 * * *$ & $0.68 *$ \\
\hline R\&D exp. 2009-11 & $0.64 * * *$ & $0.61 * * *$ & 0.42 & $0.72 * * *$ & $0.59 * * *$ & $0.50^{*}$ \\
\hline R\&D exp. 2012-14 & $0.54 * *$ & $0.53 * * *$ & 0.33 & $0.68 * * *$ & $0.53 * * *$ & $0.41^{*}$ \\
\hline Patents/capita 2006-8 & 0.43 & $0.46^{*}$ & $0.27 *$ & $0.61 *$ & 0.46 & 0.45 \\
\hline Patents/capita 2009-11 & 0.35 & 0.40 & $0.17^{*}$ & $0.58 *$ & 0.41 & 0.37 \\
\hline Patents/capita 2012-14 & 0.32 & 0.40 & $0.11 *$ & $0.59 *$ & 0.40 & 0.34 \\
\hline GII score $2006-8$ & $0.80^{* * *}$ & $0.76^{* * *}$ & 0.24 & $0.90 * * *$ & $0.74 * * *$ & $0.62 * *$ \\
\hline GII score 2009-11 & $0.83^{* * *}$ & $0.86^{* * *}$ & 0.28 & $0.88 * * *$ & $0.84 * * *$ & $0.71 * * *$ \\
\hline GII score 2012-14 & $0.83 * * *$ & $0.87 * * *$ & 0.27 & $0.88 * * *$ & $0.85^{* * *}$ & $0.71 * * *$ \\
\hline GDP growth 2006-8 & $-0.33 * *$ & $-0.41 * * *$ & $-0.39 *$ & $-0.33^{*}$ & $-0.43 * * *$ & $-0.44 * * *$ \\
\hline GDP growth 2009-11 & 0.03 & 0.02 & $-0.39 * *$ & 0.16 & -0.03 & $-0.21 * * *$ \\
\hline GDP growth 2012-14 & 0.09 & $-0.09 *$ & $-0.58 * * *$ & 0.06 & -0.13 & $-0.17 * *$ \\
\hline HDI $2006-8$ & $0.82^{* * *}$ & $0.85^{* * *}$ & 0.28 & $0.76^{* * *}$ & $0.83^{* * *}$ & $0.82 * * *$ \\
\hline HDI 2009-11 & $0.82 * * *$ & $0.85^{* * *}$ & 0.26 & $0.79 * * *$ & $0.83^{* * *}$ & $0.77 * * *$ \\
\hline HDI 2012-14 & $0.82 * * *$ & $0.84 * * *$ & 0.25 & $0.79 * * *$ & $0.82 * * *$ & $0.77 * * *$ \\
\hline NIC 2006-8 & $0.79 * * *$ & $0.91 * * *$ & 0.24 & $0.80 * * *$ & $0.90 * * *$ & $0.72 * * *$ \\
\hline Nobel prize/capita & $0.50 * * *$ & $0.41 * * *$ & -0.17 & $0.58 * * *$ & $0.50 * *$ & $0.35^{*}$ \\
\hline $\begin{array}{l}\text { Global Entrepreneur- } \\
\text { ship Index 2012-14 }\end{array}$ & 1.00 & $0.84 * * *$ & 0.25 & $0.79 * * *$ & $0.82^{* * *}$ & $0.71 * * *$ \\
\hline $\begin{array}{l}\text { Quality of gov't } \\
\text { 2012-14 }\end{array}$ & & 1.00 & 0.35 & $0.84 * * *$ & $0.99 * * *$ & $0.84 * * *$ \\
\hline $\begin{array}{l}\text { Quantity of gov't } \\
\text { 2012-14 }\end{array}$ & & & 1.00 & 0.17 & 0.36 & 0.42 \\
\hline $\begin{array}{l}\text { Global Competitiveness } \\
\text { Index 2012-14 }\end{array}$ & & & & 1.00 & 0.82 & $0.64 * *$ \\
\hline Rule of Law 2012-14 & & & & & 1.00 & $0.85^{* * *}$ \\
\hline $\begin{array}{l}\text { Democracy Index } \\
\text { 2012-14 }\end{array}$ & & & & & & 1.00 \\
\hline
\end{tabular}

Legend: $\quad * * * \mathrm{p}>.001 ; * * \mathrm{p}>.01 ; * \mathrm{p}>.05$.

Notes:

a Global Entrepreneurship Index average over 2014-16.

b Measured as the average of the six factors for each country in the Worldwide Governance Indicators dataset over 2012-14.

c Average government expenditure as share of GDP during 2012-14.

d Global Competitiveness Index average over 2012-14.

e World Justice Project's Rule of Law Index average over 2012-14.

f Economist Intelligence Unit's Democracy Index average over 2012-14.

Sources: Ács et al. (2014, 2015, 2016); Economist Intelligence Unit (2012, 2013, 2014); World Economic Forum (2012, 2013, 2014); World Justice Project (2013, 2014); INSEAD (2007, 2009, 2010); INSEAD and WIPO (2012); Cornell University, INSEAD, and WIPO (2013, 2014); Lin et al. (2014); OECD statistics $(<$ https://stats.oecd.org/>), UNDP statistics (<http://hdr.undp.org/en/data $>)$, and World Bank statistics $(<$ https://data.worldbank.org/>) collected in 2013 through 2018 (all read April 1, 2018). 
carried out from 2004-7 and second an international investigation consisting of a large number of field studies in Asia, Europe and the US carried out during various field trips during the years 2008-15. The latter is referred to in this book as the international investigation as opposed to the former national investigation. To some extent the book also draws on a research project carried out from 2008-12, called the MELT-project - Management, Economics, Law and Technology of open innovation and IP. The package of sub-studies in the national investigation was designed in order to provide a broad evidence-based approach to policy making that would integrate patent and IP policies in their relevant context of innovation, entrepreneurship and growth policies. The methodology was moreover to be scalable, i.e. the study package design should be possible to use for larger samples in larger economies, and adaptable to studies in other countries in general.

The field studies in Asia, Europe and the US were aimed at exploring the developments of innovation and IP policies (IIP policies) in various countries, particularly new entrants in the innovation and IP area from Asia, i.e. China, India and S. Korea, besides Japan, and to contextualize the findings from the first part. As will be elaborated upon in the book, the normative findings from the policy studies in the national investigation were to a considerable extent generalizable, at the same time as IIP policies and policy ambitions have become quite similar across many countries, i.e. there is a certain IIP policy convergence, as will be elaborated in the book, as well.

\subsubsection{Book Outline and Reading Guidelines}

This book can be partitioned into six parts. The first part consists of Chapters 1,2 and 3, which serve as an introduction to the topics of $R \& D$, patenting, innovations and growth in a macro-economic as well as in a micro-economic perspective. These chapters are linked to the purpose of analysing the relations between $\mathrm{R} \& \mathrm{D}$, patenting, innovations, growth and welfare. The second part consists of Chapters 4, 5 and 6 in which these relations are further elaborated on, based on the various sub-studies of the Swedish national investigation. In Chapter 4 the methodology of the national as well as the international investigation is explained. Chapter 5 goes through the various sub-studies in the national Swedish investigation and presents an analysis of each of them. Chapter 6 then gives an empirical account connected with the government investigation's special task of explaining the decrease in patenting frequency in Sweden in the early 2000s and explaining fluctuations in patenting frequency more generally. The third part consists of Chapter 7 , presenting general policy recommendations linked to the relations between $R \& D$, patenting, innovations and growth, and Chapter 8 , presenting special recommendations that would increase awareness and understanding of patenting costs and benefits, and recommendations that would improve the use of the patent system and the patenting propensity in companies. These recommendations are based mainly on the findings in the first and second parts.

The fourth part consists of Chapters 9 and 10 and presents results from the international investigation (apart from those in Chapter 1). Chapter 9 presents an overview of innovation and patent policy developments and issues in various selected countries and regions around the world, followed by transnational policy recommendations and policy issues in Chapter 10 that draw from both the national and international investigation. 
Chapter 10 also gives a number of recommendations for further IP policy research. The fourth part is designed so that, by and large, it could be read independently of other parts. This is also true for the first and second parts and, for a reader with certain background knowledge in economics and patenting, the third part as well. The fifth part consists of Chapters 11 and 12. Chapter 11 adopts an overall global macro-economic perspective and addresses a need to build and strengthen institutions for global innovation systems in which IPRs could function as important governance tools. Chapter 11 also speculates about the future of capitalist institutions and the IPR system and its role in particular. Chapter 12 provides a summary of the entire book and its conclusions. Finally, the sixth part consists of a few appendices with questionnaires and a glossary. Figure 1.4 gives an overview of the chapter structure of the book together with some reading guidelines.

\subsection{CHAPTER SUMMARY AND CONCLUSIONS}

This chapter has outlined the book and its main aim to increase our understanding how R\&D of new technologies, patents and innovations can contribute to growth and welfare in society. By viewing our history and future through a time window $20+$ years back and ahead a number of global forces and key trends can be identified and a number of grand questions about innovation policies and systems be raised. Some of these questions will in all modesty be addressed in this book, based on empirical studies at national and international levels. After an introduction of key concepts in the book, the chapter elaborated on some of the key forces and trends, i.e. (a) the continued evolution of a globalizing economy based on capitalist institutions and intellectual (knowledge, intangible) capital, i.e. a knowledge-based capitalist economy or in other words intellectual capitalism, and the key enabling role of infocom technologies (ICTs) and digitalization; (b) a globalizing pro-IP era; (c) international adoption of IIP policies, especially in key Asian countries; (d) emergence of new generic and recombinant technologies and (e) the emergence of more and larger global challenges.

Accounting for IC presents a number of difficulties. Nevertheless various indicators presented in the chapter show the growing importance, if not dominance, of IC and capitalism. In fact, few observers nowadays question the emergence of an increasingly knowledge-based economy, although calling it "the new economy" can be questioned. The novelty is that the economy has come to be dominated by IC in various forms, defined as non-physical and non-financial capital. At the same time, fundamental old capitalistic institutions have survived and, consistently, intellectual property rights have become much more important, fostering the emergence of a new IP regime with a pro-patent era since the 1980s. Its effects are pervasive on numerous levels, not least internationally. Countries and companies are equipping themselves with reinforced IPRs as competitive means, led since the 1980s and 1990s by the US and Japan and later by S. Korea and China and later likely also by India and other nations. These countries thereby further increase their technology-based competitiveness, just as happened previously in Japan. The chapter presented statistics showing the strong growth of patenting worldwide and in major Asian countries in particular during the last 40 years or so. New protective technologies are moreover developing which support the capitalization and 
Part I: Introduction

Chapter 1: Innovation, IP and intellectual capitalism

Chapter 2: Analytical framework

Chapter 3: Patents and innovations for growth and welfare - a literature review

Part II: The national investigation's empirical studies

Chapter 4: Methodology

Chapter 5: Patents, innovations and growth - empirical analysis

Chapter 6: What explains fluctuations in patenting frequency and propensity?

Part III: The national investigation's recommendations

Chapter 7: Discussion and general innovation and IP policy recommendations

Chapter 8: Special recommendations for increasing patent knowledge and patenting

Part IV: The international investigation

Chapter 9: Patent and innovation system developments in Europe, Asia and the US

Chapter 10: Transnational policy recommendations and policy issues

Part V: Summary and Conclusions

Chapter 11: Global innovation and intellectual capitalism

Chapter 12: Summary and conclusions

Part VI: Appendices

Questionnaires

Glossary

Note: a The vertical arrows indicate suitable reading sequences. Most parts can be read by and large independently, however.

Figure 1.4 Book outline and reading guidelines ${ }^{a}$

propertization of data, information and knowledge and thus IC and property formation, e.g. in "big data".

From being secondary and somewhat obscure matters for specialists, IP issues have become strategic and major political and management issues. Simultaneously, difficulties have arisen for integrating these issues with other economic policies and company strategies, giving rise to problems with policy gaps and strategy gaps, gaps which the book attempts to narrow.

The chapter introduced a simple model of innovation, linking the key focal factors in the book, i.e. $\mathrm{R} \& \mathrm{D} / \mathrm{knowledge,} \mathrm{patents/IP,} \mathrm{innovations} \mathrm{and} \mathrm{entrepreneurship,}$ growth and welfare in a feedback loop, a model referred to as the innovation spiral 
and used throughout the book. The chapter then presented a comparative analysis of how selected countries, including OECD countries, scored on the key focal factors or variables in the innovation spiral for selected time periods in the 2000s, and how well these variables correlated. S. Korea, Nordic countries, Switzerland and Israel ranked high in general, as did larger countries such as the US, Germany and Japan. Sweden ranked fairly high among OECD countries on R\&D/GDP, patents p.c. and welfare and very high on innovativeness. A statement that most highly innovative countries are small had limited support (just as there is limited support for claiming that most highly innovative firms are small). On the other hand most best performing countries regarding welfare indicators were small. Data and indicator limitations and ranking volatility over time call for caution in interpretation, however. The limited time series and the inherent feedback in the innovation spiral moreover prevented any statistical causal analysis.

All variables in the innovation spiral were positively correlated across countries, except GDP growth which showed negative correlations with all other variables, likely due to the financial crisis in 2008-10 and the ensuing great recession. Growth was thus not positively connected to welfare indicators, which could be taken as support for the so-called Easterlin paradox (see further Chapter 3), but the limited data, distorted by the financial crisis, prevents such a conclusion. Nor could any conclusion about economic convergence be drawn. R\&D was fairly strongly (positively) correlated with patents, innovation and welfare while patents were positively but weaker correlated with innovation and welfare, and the latter two more strongly correlated. Incidentally Nobel Prizes in S\&T per capita were fairly strongly correlated with $\mathrm{R} \& \mathrm{D}$, innovativeness and welfare but not at all with patents p.c., nor with growth. The patents p.c. variable was also uncorrelated with GDP p.c.

Innovation spiral variables at country level are embedded in national innovation systems and an institutional environment. The chapter therefore probed how the selected countries scored on the qualities of institutions related to government and infrastructure, firms and entrepreneurship, markets and competitiveness, property rights and rule of law, and democracy, and how these institutional variables correlated with innovation spiral variables.

Small and mostly old Western European countries were found to dominate the set of top-10 countries regarding entrepreneurship, quality of government, competitiveness, rule of law and democracy and EU countries dominated among the top-10 regarding quantity of government (measured as the government expenditure share of GDP). Thus age, size and European origin mattered for these national institutional qualities. All the indices for institutional qualities except quantity of government strongly correlated positively with all innovation spiral variables except patents and growth, although with less significance between democracy and R\&D. There was moreover a noteworthy and surprising weak connect between quality and quantity of government, both in relation to other institutional qualities and in relation to innovation spiral variables, which calls for further exploration.

Thus, one may hypothesize that large low quality governments on average are connected with weak innovation spirals, while strong innovation spirals on average are connected with small countries with high quality democratic governments and strong rule of law (with caveats about the growth factor since it was distorted by the financial crisis 
in 2008-11). These results must be treated with caution, however, due to imperfect data and limited methods.

This introductory chapter finally outlined the chapter structure in the book together with reading guidelines. 